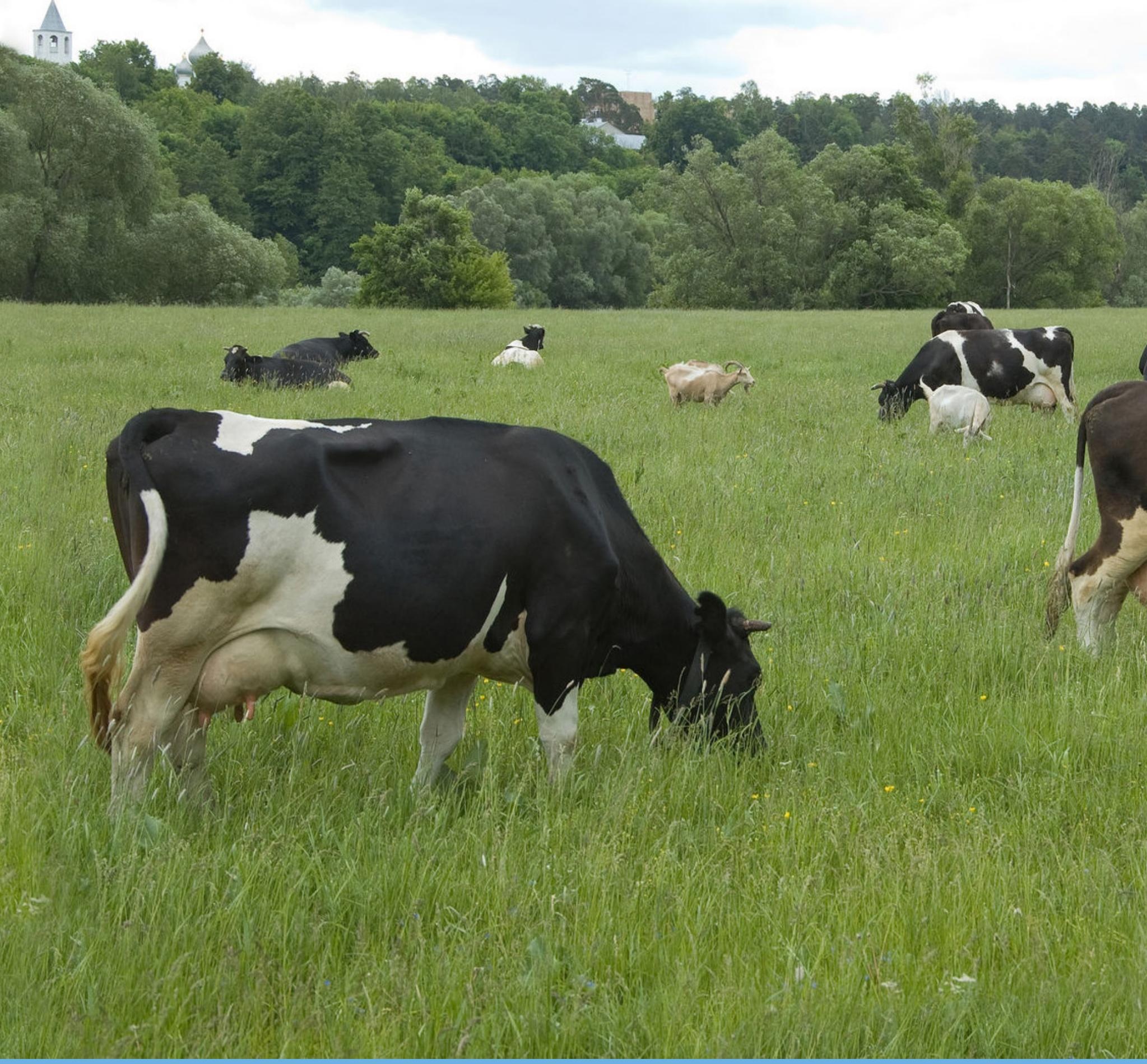

\title{
Excretieforfaits melkvee
}

Actualisatie 2021

L.B. Šebek en C. van Bruggen

OPENBAAR

Rapport 1330

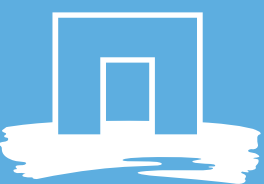





\section{Excretieforfaits melkvee}

Actualisatie 2021

\section{Auteurs}

L.B. Šebek ${ }^{1}$ en C. van Bruggen ${ }^{2}$

1 Livestock Research Wageningen

2 Centraal Bureau voor de Statistiek

Dit onderzoek is uitgevoerd door Wageningen Livestock Research en gesubsidieerd door het ministerie van Landbouw, Natuur en Voedselkwaliteit, in het kader van het Beleidsondersteunend onderzoek thema 'Verminderen fossiele nutriënten en emissies naar bodem, water en lucht' (projectnummer BO-43-101-002).

Wageningen Livestock Research

Wageningen, november 2021

Openbaar

Rapport 1330 
Šebek, L. B. en van Bruggen, C. 2021. Excretieforfaits melkvee; Actualisatie 2021. Wageningen Livestock Research, Openbaar Rapport 1330.

De excretieforfaits voor stikstof en fosfaat van melkkoeien zijn vastgelegd in bijlage $D$ van de Uitvoeringsregeling Meststoffenwet. Deze excretieforfaits worden periodiek geactualiseerd. Bij de actualisatie in 2021 is de methode om excretieforfaits te bepalen verfijnd door met verschillende rantsoenen per melkproductieklasse te werken. Die verfijning was mogelijk door gebruik te maken van een KringloopWijzer dataset over de jaren 2017, 2018 en 2019. Met deze dataset is ook onderbouwd dat de geactualiseerde forfaits een goede weergave zijn van de excreties van stikstof en fosfaat door melkkoeien die tussen de 3000 - $13000 \mathrm{~kg}$ melk per dier per jaar produceren. De nieuwe excretieforfaits verschillen van de huidige excretieforfaits met name voor fosfaat. Daardoor verandert de productieruimte per melkproductieklasse met als totaal resultaat een verwachte toename van de totale fosfaatproductie in mest door melkvee van 3,6 miljoen $\mathrm{kg}$ fosfaat per jaar. Wanneer de extra productieruimte op basis van fosfaat via het fosfaatrechtenstelsel daadwerkelijk wordt opgevuld, dan zou de totale stikstofexcretie door melkvee toe met ongeveer 13-14 miljoen kg stikstof per jaar toenemen.

The Dutch standards for the excretion of nitrogen and phosphorus in manure by dairy cows are listed in Table II of the Implementing Regulation. These standards are updated regularly. During the 2021 update, the calculation method was refined by using milk production specific diets. This refinement was based on a dataset derived from the Dutch Annual Nutrient Cycling Assessment, including data from nearly all dairy farms over the years 2017, 2018 and 2019. Based on this dataset, it was shown that the updated standards for the excretion of nitrogen and phosphorus in manure by dairy cows are in line with the observed excretion of nitrogen and phosphorus in manure by dairy cows producing between 3.000 and $13.000 \mathrm{~kg}$ milk per cow per year. The updated standards differ from the current standards, especially for phosphate. Implementation of the new standards in the so-called Phosphate Production Act would increase the room for manure production by the Dutch dairy herd by 3,6 million $\mathrm{kg}$ of phosphate and by 13-14 million $\mathrm{kg}$ of nitrogen per year.

Dit rapport is gratis te downloaden op https://doi.org/10.18174/559242 of op www.wur.nl/livestock-research (onder Wageningen Livestock Research publicaties).

\section{(cc) BY-NC}

Dit werk valt onder een Creative Commons Naamsvermelding-Niet Commercieel 4.0 Internationaallicentie.

(C) Wageningen Livestock Research, onderdeel van Stichting Wageningen Research, 2021 De gebruiker mag het werk kopiëren, verspreiden en doorgeven en afgeleide werken maken. Materiaal van derden waarvan in het werk gebruik is gemaakt en waarop intellectuele eigendomsrechten berusten, mogen niet zonder voorafgaande toestemming van derden gebruikt worden. De gebruiker dient bij het werk de door de maker of de licentiegever aangegeven naam te vermelden, maar niet zodanig dat de indruk gewekt wordt dat zij daarmee instemmen met het werk van de gebruiker of het gebruik van het werk. De gebruiker mag het werk niet voor commerciële doeleinden gebruiken.

Wageningen Livestock Research aanvaardt geen aansprakelijkheid voor eventuele schade voortvloeiend uit het gebruik van de resultaten van dit onderzoek of de toepassing van de adviezen.

Wageningen Livestock Research is NEN-EN-ISO 9001:2015 gecertificeerd.

Op al onze onderzoeksopdrachten zijn de Algemene Voorwaarden van de Animal Sciences Group van toepassing. Deze zijn gedeponeerd bij de Arrondissementsrechtbank Zwolle. 


\section{Inhoud}

$\begin{array}{ll}\text { Woord vooraf } & 5\end{array}$

$\begin{array}{ll}\text { Samenvatting } & 7\end{array}$

1

Inleiding

11

Gebruik data KringloopWijzer 12

2.1 Werkwijze $\quad 12$

2.1.1 Opschonen dataset 12

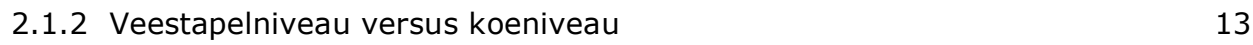

2.2 Analyse 14

2.3 Trends over melkproductieklassen $\quad 14$

2.3.1 Algemeen 14

2.3.2 Rantsoenkenmerken 14

2.3.3 Kwaliteit van het rantsoen $\quad 15$

2.3.4 Opname, vastlegging en excretie $\quad 15$

2.3.5 KLW excretie versus excretie volgens de huidige
schattingsformules

$\begin{array}{llr}2.4 & \text { Conclusies } & 18\end{array}$

$3 \quad$ Aanpassen berekening forfaitaire excretie $\quad 20$

$\begin{array}{lll}3.1 & \text { Algemeen } & 20\end{array}$

3.2 Aanpassing van de schattingsformules $\quad 21$

3.2.1 Samenstelling schattingsformules $\quad 21$

3.2.2 Werkwijze $\quad 21$

3.2.3 Vaststellen specifiek rantsoen per melkproductieklasse $\quad 22$

3.2.4 Update richtingscoëfficiënten schattingsformules 23

$\begin{array}{lll}3.3 & \text { Conclusies } & 24\end{array}$

$4 \quad$ Impact nieuwe schattingsformules $\quad 25$

4.1 Nieuwe schattingsformules versus KLW data 25

$\begin{array}{lll}4.2 & \text { Huidige forfaits versus voorgestelde nieuwe forfaits } & 27\end{array}$

$\begin{array}{ll}4.2 .1 \text { Algemeen } & 27\end{array}$

4.2.2 N-excretie $\quad 27$

4.2.3 $\mathrm{P}_{2} \mathrm{O}_{5}$-excretie $\quad 28$

$\begin{array}{lll}4.3 \text { Conclusies } & 29\end{array}$

$5 \quad$ Voorgestelde forfaits en productieruimte $\quad 30$

$\begin{array}{lll}5.1 & \text { Inleiding } & 30\end{array}$

5.2 Uitgangspunten 30

$\begin{array}{lll}5.3 & \text { Gebruikte data } & 30\end{array}$

5.4 Resultaten en conclusies $\quad 33$

$\begin{array}{lll}5.4 .1 & \text { Fosfaatexcretie } & 33\end{array}$

5.4.2 Stikstofexcretie $\quad 34$

5.4.3 Gevolgen op bedrijfsniveau $\quad 35$

$\begin{array}{llr}6 & \text { Conclusies } & 38\end{array}$

$\begin{array}{ll}\text { Literatuur } & 40\end{array}$

$\begin{array}{lll}\text { Bijlage 1 } & \text { Trends in rantsoenen (1) } & 41\end{array}$

$\begin{array}{lll}\text { Bijlage } 2 & \text { Trends in rantsoenen (2) } & 42\end{array}$ 
Bijlage 3 Verband tussen $\mathrm{N}$ - en $\mathrm{P}_{2} \mathrm{O}_{5}$ - excretie en melkproductieniveau

Bijlage 4 Voorstel nieuwe forfaitaire excretietabel: drijfmest

Bijlage 5 Voorstel nieuwe forfaitaire excretietabel: vaste mest 


\section{Woord vooraf}

De Commissie van Deskundigen Meststoffenwet (CDM) is in het najaar van 2003 ingesteld op verzoek van het ministerie van Landbouw, Natuur en Voedselkwaliteit (LNV). De taak van de CDM is om het ministerie van LNV te adviseren over de wetenschappelijke onderbouwing en werking van de Meststoffenwet. De CDM valt als onafhankelijke wetenschappelijke commissie onder de unit WOT Natuur \& Milieu van Wageningen University \& Research. De CDM adviseert het ministerie van LNV over het mest- en ammoniakbeleid in het algemeen en specifiek over gewenste aanpassingen van aannames, regels, normen, onderbouwingen en forfaits in de Meststoffenwet.

De gebruiksnormen voor dierlijke mest en voor stikstof en fosfaat zijn belangrijke pijlers van het Nederlandse mest- en ammoniakbeleid. Om de gebruiksnormen in de praktijk toe te passen, is het van belang dat veehouders nauwkeurig kunnen berekenen hoeveel stikstof en fosfaat in de dierlijke mest, die op een bedrijf wordt geproduceerd, aanwezig is. Houders van staldieren die geen gebruik maken van de stalbalansmethode waarbij wordt uitgegaan van de werkelijk gemeten gehalten in de afgevoerde mest en melkveehouders die in het kader van de vrije bewijsleer geen gebruik maken van de Handreiking bedrijfsspecifieke excretie melkvee (BEX), maken gebruik van zogenoemde excretieforfaits in Tabel I van bijlage D van de Uitvoeringsregeling Meststoffenwet.

Op verzoek van het ministerie van LNV heeft de CDM de excretieforfaits voor melkvee van de Uitvoeringsregeling Meststoffenwet beoordeeld en adviezen opgesteld voor geactualiseerde excretieforfaits. Het advies is opgesteld door medewerkers van Wageningen University \& Research (Wageningen Livestock Research) en Centraal Bureau voor de Statistiek (CBS) en gereviewd door leden van de CDM.

Drs. R.M.A. (Roselinde) Goselink

Afdelingshoofd Diervoeding

Wageningen Livestock Research 


\section{Samenvatting}

\section{Inleiding}

De excretieforfaits voor melkkoeien zijn vastgelegd in bijlage D van de Uitvoeringsregeling Meststoffenwet met daarin tabel IIA voor drijfmest en tabel IIB voor vaste mest. De excreties van stikstof $(\mathrm{N})$ en fosfaat $\left(\mathrm{P}_{2} \mathrm{O}_{5}\right)$ zijn weergegeven in $\mathrm{kg}$ per koe per jaar, per melkproductieklasse van $250 \mathrm{~kg}$ voor de range van 5.624 tot $10.624 \mathrm{~kg}$ melk per koe per jaar. Voor lagere en hogere melkproducties per koe gelden de forfaits van de laagste respectievelijk hoogste klasse in de tabel. De huidige excretieforfaits geven de gemiddelde excretie weer over de jaren 2010, 2011 en 2012. Dat waren de drie jaren waarvoor recente data beschikbaar waren voor het afleiden van de forfaits in 2014. Er wordt onderscheid gemaakt tussen bruto excreties ('excretie onder de staart') en excreties gecorrigeerd voor gasvormige stikstofverliezen uit stallen en mestopslagen. De tabellen IIA en IIB geven de $\mathrm{N}$-excreties gecorrigeerd voor gasvormige stikstofverliezen weer.

De excretieforfaits worden periodiek herzien en eventueel aangepast aan ontwikkelingen in de melkveehouderij en/of op basis van nieuwe wetenschappelijke inzichten. Bij de voorliggende actualisatie 2021 zijn twee aanvullende vragen gesteld:

1. Kan tabel II worden uitgebreid met melkproductieklassen lager dan 5.624 en hoger dan $10.624 \mathrm{~kg}$ melk per jaar?

2. Passen de rekenregels die gebruikt worden om de forfaits af te leiden nog bij de actuele situatie?

Om deze vragen te beantwoorden is gebruik gemaakt van ruwe data van de KringloopWijzer (KLW) over de jaren 2017, 2018 en 2019. Deze KLW-dataset omvat gegevens van bijna 15.000 melkveebedrijven per jaar, met voor genoemde jaren een totaal van 44.436 bedrijven. De dataset omvat daarmee ca. $95 \%$ van de gehele Nederlandse melkveestapel. Uit deze dataset bleek dat de klassen lager dan 3.000 en hoger dan 13.000 kg melk per koe per jaar ieder minder dan 50 bedrijven tellen, wat als te weinig is beschouwd voor het vaststellen van een representatief beeld van een bepaalde klasse. Deze actualisatie heeft daarom betrekking op de melkproductierange van 3.000 tot $13.000 \mathrm{~kg}$ melk per koe per jaar. Onderhavig rapport geeft voorstellen voor actualisatie van de huidige forfaits. Eerder gedane voorstellen voor aanpassingen in 2019, op basis van cijfers over 2015, 2016 en 2017 zijn destijds, na discussie met de sector, niet door het ministerie van LNV geaccordeerd.

De analyses zijn uitgevoerd door een werkgroep van de Commissie Deskundigen Meststoffenwet (CDM). Resultaten van de analyses en voorstellen voor aanpassingen zijn tussentijds besproken met vertegenwoordigers van de melkveesector, veevoerleveranciers en het ministerie van LNV. Het voorstel voor aanpassing van de excretieforfaits wordt door de CDM aangeboden aan het ministerie van LNV, die uiteindelijk bepaald of de aangepaste excretieforfaits in de praktijk worden geïmplementeerd door wijziging van de tabellen IIA en IIB van de Uitvoeringsregeling Meststoffenwet.

\section{Uitbreiden melkproductieklassen en samenstelling rantsoen per klasse}

$\mathrm{Er}$ is onderzocht of er tussen melkproductieniveaus verschillen bestaan voor wat betreft de bij de excretieberekening gebruikte kengetallen (rantsoensamenstelling, VEM-, N- en P-gehaltes ${ }^{1}$ in de voedermiddelen en melksamenstelling). Nieuw in de voorliggende actualisatie is dat rantsoenverschillen tussen melkproductieklassen zijn meegenomen. De melkveebedrijven van de KringloopWijzer zijn ingedeeld naar melkproductie in klassen van $1000 \mathrm{~kg}$ melk per koe voor het traject 3.000 tot $13.000 \mathrm{~kg}$ melk per koe per jaar. Er bleken duidelijke melkproductieniveaugerelateerde lineaire trends te zijn voor de samenstelling van het rantsoen, de daarmee samenhangende voederwaarde (VEM, g N en g P per kg droge stof en g N en g P per kVEM) en de daarmee berekende opname, vastlegging en excretie van stikstof en fosfaat. Op basis daarvan is de

\footnotetext{
${ }^{1}$ Excreties worden uitgedrukt in $\mathrm{kg}$ fosfaat $\left(\mathrm{P}_{2} \mathrm{O}_{5}\right)$, maar de gehaltes van fosfor $(\mathrm{P})$ in veevoer, melk en in dieren worden uitgedrukt in $\mathrm{g}$ P. Voor de omrekening van fosfor $(\mathrm{P})$ naar fosfaat $\left(\mathrm{P}_{2} \mathrm{O}_{5}\right)$ in de excretie wordt een factor 2,29 gebruikt.
} 
conclusie getrokken dat voor het berekenen van de excretie van melkkoeien lineaire verbanden gebruikt kunnen worden in de melkproductierange van 3.000 tot $13.000 \mathrm{~kg}$ melk per koe per jaar.

\section{Aanpassen rekenregels}

De rekenregels c.q. schattingsformules, waarmee de excretieforfaits worden afgeleid, maken gebruik van lineaire verbanden die zijn afgeleid voor de relaties tussen de $\mathrm{N}$ - en $\mathrm{P}_{2} \mathrm{O}_{5}$-excreties en het melkproductieniveau, op basis van de data van de KringloopWijzer. De gemiddelde waarden per melkproductieklasse voor het melkureumgehalte.en de $\mathrm{N}$-excretie en $\mathrm{P}_{2} \mathrm{O}_{5}$-excretie worden bij iedere actualisatie van de excretieforfaits aangepast aan de door het CBS geobserveerde gemiddelde waarden over de laatste 3 beschikbare jaren (CBS maakt gebruik van de cijfers van de Werkgroep Uniformering Mestcijfers - WUM). In deze actualisatie is het CBS-gemiddelde over de jaren 2017, 2018 en 2019 gebruikt.

In de voorliggende actualisatie is onderzocht of het gebruik van lineaire verbanden nog past bij de huidige melkveehouderij. Hiervoor zijn de trends van de verbanden tussen $\mathrm{N}$ - en $\mathrm{P}_{2} \mathrm{O}_{5}$-excreties en het melkproductieniveau onderzocht met data van de KringloopWijzer. Daarmee is inzichtelijk gemaakt of de in de Nederlandse praktijk gebruikelijke voerstrategieën per melkproductieklasse zorgen voor afwijkingen van een lineair verband tussen excretie en melkproductie.

Bij het berekenen van de excreties in de KringloopWijzer wordt voor de VEM-behoefteberekening gebruik gemaakt van de rekenregels van het Centraal Veevoeder Bureau (CVB). Ook de WUM maakt gebruik van deze rekenregels. Op basis van de VEM-behoefte en de samenstelling van de rantsoenen wordt de voeropname en de $\mathrm{N}$ - en P-opname berekend, waarna met de balansmethode (excretie = opname - vastlegging) de excretie wordt berekend. Vervolgens is de relatie tussen melkproductie en excretie vastgesteld door middel van regressieanalyse. Deze relatie is vergeleken met de relatie waarmee in de huidige forfaits wordt gerekend. Het bleek dat de relatie tussen melkproductie en excretie is veranderd, onder andere omdat in de voorliggende actualisatie rekening is gehouden met rantsoenverschillen tussen melkproductieklassen.

Verder zijn de nu voorgestelde forfaitaire excreties afgeleid met dezelfde methode als de huidige forfaits (Bikker et al, 2019), uitgezonderd één wijziging: het rantsoen is per melkproductieklasse afgeleid uit de KLW-dataset 2017, 2018 en 2019. Voorheen werd een gestandaardiseerd rantsoen voor alle melkproductieklassen gebruikt, waarbij de ruwvoer/krachtvoer verhouding per melkproductieklasse werd aangepast. In de onderhavige actualisatie zijn dus met de rantsoenen van de KLW-dataset, en voor de melkproductierange van 3.000-13.000 kg per jaar, de $\mathrm{N}_{\text {en }} \mathrm{P}_{2} \mathrm{O}_{5}$-excreties berekend.

\section{Resultaten}

Met behulp van regressieanalyse is de richtingscoëfficiënt bepaald van de relatie tussen excretie en melkproductie. Dat is voor zowel $\mathrm{N}$ als $\mathrm{P}_{2} \mathrm{O}_{5}$ gebeurd. De schattingsformules met de nieuwe richtingscoëfficiënten zijn:

$\mathrm{N}$-excretie, in kg per koe per jaar $=145,6+0,0079365 \times($ melk -8797$)+1,8 \times($ ureum $-22,5)$

$\mathrm{P}_{2} \mathrm{O}_{5}$-excretie, in $\mathrm{kg}$ per koe per jaar $=40,6+0,0015533 \times($ melk -8797$)$

Waarin 145,6 en 40,6 de gemiddelde excreties zijn per koe in Nederland voor respectievelijk $N$ en $P_{2} O_{5}$, melk is de bedrijfsspecifieke melkproductie, 8797 is de gemiddelde melkproductie in Nederland

( $\mathrm{kg} / \mathrm{koe} / \mathrm{jaar})$, ureum is het bedrijfsgemiddelde melkureumgehalte $(\mathrm{mg} / 100 \mathrm{~g})$ en 22,5 is het gemiddelde melkureumgehalte in Nederland.

Voor het gemiddelde over de jaren 2017, 2018 en 2019 komen de excreties van stikstof en fosfaat volgens de nieuwe schattingsformules overeen met de gemiddelde excreties van stikstof en fosfaat volgens CBS/WUM. Het verschil tussen de excretie volgens de nieuwe schattingsformule en de geobserveerde excretie in de KLW-dataset bedragen per melkproductieklasse maximaal 5\% en zijn niet afhankelijk van het melkproductieniveau. Daarmee sluiten de excreties berekend met de nieuwe schattingsformules goed aan bij de waargenomen excreties in de praktijk. Echter, de excreties volgens de nieuwe schattingsformules wijken af van de excreties volgens de huidige forfaits. Dit verschil is 
afhankelijk van het melkproductieniveau. Figuur S.1 illustreert de verschillen tussen de excreties volgens de nieuwe schattingsformules en de huidige forfaits.
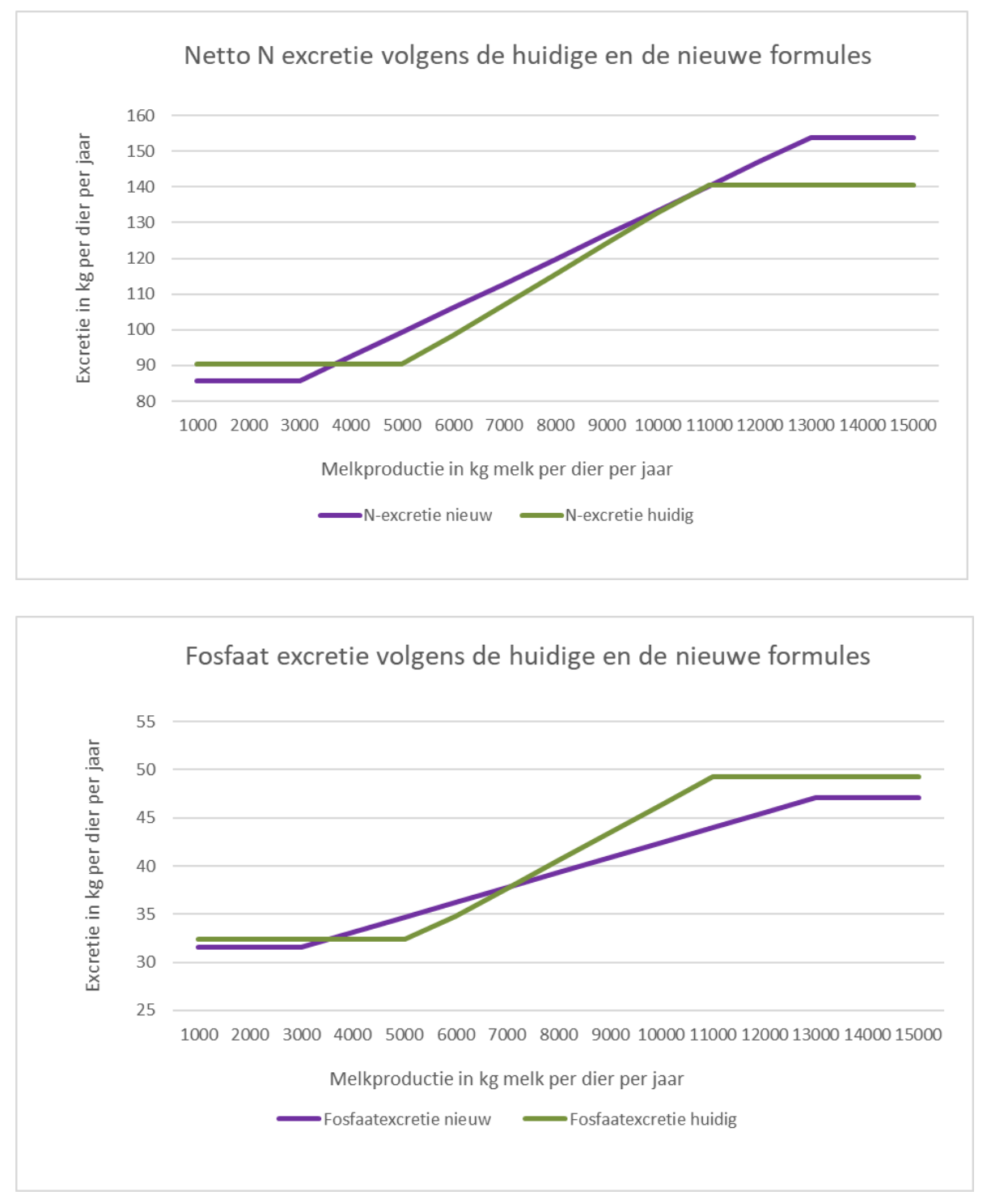

Figuur S.1 De stikstofexcretie (bovenste figuur) en de fosfaatexcretie (onderste figuur), in $\mathrm{kg}$ per koe per jaar, als functie van het melkproductieniveau; resultaten van de huidige forfaits (groene lijn, excretie huidig) en van de voorgestelde nieuwe schattingsformules (paarse lijn, excretie nieuw). Merk op dat de huidige excretieforfaits en de voorgestelde nieuwe forfaits niet over hetzelfde melkproductietraject zijn gedifferentieerd.

De nieuwe $\mathrm{N}$-excreties zijn hoger of gelijk aan de huidige forfaits voor de klassen van $4000-15000 \mathrm{~kg}$ melk, maar lager voor de klassen van 1000 - $4000 \mathrm{~kg}$ melk. De nieuwe fosfaatexcreties zijn lager dan de huidige forfaits voor de klassen van 7000 - $15000 \mathrm{~kg}$ melk, hoger voor de klassen van 4000-7000 $\mathrm{kg}$ melk en iets lager voor de klassen van 1000 - $4000 \mathrm{~kg}$ melk.

$\mathrm{Bij}$ implementatie in het fosfaatrechtenstelsel zouden de voorgestelde nieuwe $\mathrm{P}_{2} \mathrm{O}_{5}$-excretieforfaits per saldo de nationale productieruimte voor melk vergroten, omdat er binnen de fosfaatrechten ruimte ontstaat voor ongeveer 3,6 miljoen kg extra fosfaatproductie. Wanneer de extra productieruimte op basis van fosfaat daadwerkelijk wordt opgevuld neemt de N-excretie toe met ongeveer 13-14 miljoen $\mathrm{kg} \mathrm{N}$ per jaar, waardoor het lastig wordt om overschrijding van het stikstofplafond te voorkomen, zonder aanvullende (stikstof)maatregelen. 


\section{$1 \quad$ Inleiding}

De excretieforfaits voor melkkoeien zijn vastgelegd in de tabellen IIA (drijfmest) en IIB (vaste mest) van bijlage $D$ van de Uitvoeringsregeling Meststoffenwet. In deze tabellen is de excretie per melkproductieklasse weergegeven in de range van 5624 tot 10624 kg melk per koe per jaar. Buiten die range wordt het forfait doorgetrokken op hetzelfde niveau. Zo geldt voor alle dieren die minder dan $5375 \mathrm{~kg}$ melk produceren het forfait behorende bij een melkproductie in de range van 5125-5374 $\mathrm{kg}$ en voor alle dieren die meer dan $10624 \mathrm{~kg}$ melk produceren het forfait behorende bij een melkproductie in de range van $10875-10124 \mathrm{~kg}$. De excretieforfaits geven de gemiddelde excretie weer over drie (meest recente) jaren die beschikbaar waren ten tijde van de laatste update. Er wordt onderscheid gemaakt tussen bruto excreties ('excretie onder de staart') en excreties gecorrigeerd voor gasvormige stikstofverliezen uit stallen en mestopslagen. In dit rapport betreft het de bruto excreties, maar de forfaits in de tabellen IIA en IIB geven stikstofexcreties weer die gecorrigeerd zijn voor gasvormige stikstofverliezen.

De excretieforfaits voor stikstof $(\mathrm{N})$ en fosfaat $\left(\mathrm{P}_{2} \mathrm{O}_{5}\right)$ worden periodiek herzien en eventueel aangepast aan ontwikkelingen in de melkveehouderij en/of op basis van nieuwe wetenschappelijke inzichten (Bikker et al, 2019). Bij de laatste periodieke update (Bikker et al, 2019) is onderzocht of de forfaitaire excretietabel geëxtrapoleerd kon worden tot buiten de melkproductierange van 5624 tot 10624 kg melk per koe per jaar. Die vraag kon destijds niet adequaat beantwoord worden. Ook is bij de consultatie van de praktijk in augustus 2019 opgemerkt dat het door Bikker et al (2019) gebruikte verband tussen melkproductie en excretie in de loop van de tijd veranderd kan zijn. Beide aspecten zijn nu onderzocht en in het voorliggende rapport beschreven:

- $\quad$ Kan tabel II uitgebreid worden met melkproductieklassen lager dan 5624 en hoger dan 10624 kg melk per jaar?

- Is actualisatie van het verband tussen melkproductie en excretie gewenst?

Voor het beantwoorden van deze vragen zijn ruwe data van de KringloopWijzer (KLW) gebruikt en die data zijn ingedeeld naar melkproductieklassen van $1000 \mathrm{~kg}$. In hoofdstuk 2 wordt beschreven hoe de KLW-data zijn gebruikt om bovenstaande vragen te beantwoorden, waarbij het resultaat is dat beide vragen positief zijn beantwoord en dat deze aspecten dus moeten worden aangepast bij de actualisatie van de excretieforfaits. Vervolgens is in hoofdstuk 3 beschreven hoe de aanpassingen zijn uitgevoerd, waarna in hoofdstuk 4 de impact van die aanpassingen op de excretieforfaits inzichtelijk is gemaakt. Hoofdstuk 5 geeft een analyse van het effect van de voorgestelde nieuwe forfaits op de excretie van stikstof en fosfaat op zowel sector- als bedrijfsniveau, waarna in hoofdstuk 6 de conclusies zijn samengevat.

De analyses zijn uitgevoerd door een werkgroep van de Commissie Deskundigen Meststoffenwet (CDM). Resultaten van de analyses en voorstellen voor aanpassingen zijn tussentijds besproken met vertegenwoordigers van de melkveesector, veevoerleveranciers en het ministerie van LNV. Het voorstel voor aanpassing van de excretieforfaits is door de CDM aangeboden aan het ministerie van LNV, die uiteindelijk bepaald of de aangepaste excretieforfaits in de praktijk worden geïmplementeerd door wijziging van de tabellen IIA en IIB van de Uitvoeringsregeling Meststoffenwet. 


\section{Gebruik data KringloopWijzer}

\section{$2.1 \quad$ Werkwijze}

\subsubsection{Opschonen dataset}

De excretieforfaits worden vastgesteld op basis van gemiddelde gegevens over 3 recente, opeenvolgende jaren (Bikker et al, 2019). Daarmee in overeenstemming bevat ook de KLW-dataset voor de update van de excretieforfaits data van de meest recente 3 jaren: 2017, 2018 en 2019. De KLW-dataset bevat ruwe data (= data zoals aangeleverd door de melkveebedrijven) waarop geen controles hebben plaatsgevonden. De 'CDM-werkgroep excretieforfaits' heeft de beschikbare data enkel gecontroleerd op negatieve getallen bij de samenstelling van voedermiddelen (VEM, N en P) en de bedrijven met negatieve getallen zijn uit de dataset verwijderd. Dit opschonen van de dataset heeft geen wezenlijke invloed gehad op het aantal beschikbare bedrijven per melkproductieklasse en de representativiteit per melkproductieklassen is niet beïnvloed (Tabel 2.1). De opgeschoonde dataset is als basis gebruikt voor de update van de excretieforfaits voor melkvee. Deze ruwe KLW-dataset ${ }^{2}$ bevat nagenoeg alle Nederlandse melkveebedrijven en is daarmee representatief voor de Nederlandse melkveehouderij.

Tabel 2.1 Overzicht dataset: aantal bedrijven per melkproductieklasse voor en na opschonen plus het percentage uitval (zie tekst voor nadere uitleg over 'opschonen').

\begin{tabular}{|c|c|c|c|c|c|c|c|c|c|}
\hline \multirow{2}{*}{\begin{tabular}{|l} 
Melkklasse \\
kg per dier per jaar
\end{tabular}} & \multicolumn{3}{|c|}{ Ruwe dataset } & \multicolumn{3}{|c|}{ opgeschoond_20210325 } & \multicolumn{3}{|c|}{ Percentage uitval } \\
\hline & 2017 & 2018 & 2019 & 2017 & 2018 & 2019 & 2017 & 2018 & 2019 \\
\hline $0-3000$ & 38 & 30 & 25 & 22 & 25 & 20 & $42 \%$ & $17 \%$ & $20 \%$ \\
\hline $3000-4000$ & 85 & 76 & 57 & 66 & 68 & 51 & $22 \%$ & $11 \%$ & $11 \%$ \\
\hline $4000-5000$ & 214 & 178 & 154 & 177 & 165 & 146 & $17 \%$ & $7 \%$ & $5 \%$ \\
\hline $5000-6000$ & 634 & 512 & 473 & 529 & 495 & 450 & $17 \%$ & $3 \%$ & $5 \%$ \\
\hline $6000-7000$ & 1334 & 1122 & 1055 & 1170 & 1097 & 1021 & $12 \%$ & $2 \%$ & $3 \%$ \\
\hline $7000-8000$ & 2966 & 2593 & 2427 & 2684 & 2554 & 2391 & $10 \%$ & $2 \%$ & $1 \%$ \\
\hline $8000-9000$ & 5148 & 4559 & 4455 & 4616 & 4516 & 4418 & $10 \%$ & $1 \%$ & $1 \%$ \\
\hline $9000-10000$ & 4113 & 4271 & 4139 & 3728 & 4234 & 4105 & $9 \%$ & $1 \%$ & $1 \%$ \\
\hline $10000-11000$ & 1337 & 1692 & 1583 & 1187 & 1665 & 1572 & $11 \%$ & $2 \%$ & $1 \%$ \\
\hline $11000-12000$ & 265 & 416 & 409 & 238 & 412 & 407 & $10 \%$ & $1 \%$ & $0 \%$ \\
\hline $12000-13000$ & 28 & 69 & 80 & 26 & 69 & 79 & $7 \%$ & $0 \%$ & $1 \%$ \\
\hline $13000-14000$ & 2 & 10 & 8 & 2 & 9 & 8 & $0 \%$ & $10 \%$ & $0 \%$ \\
\hline$>14000$ & 8 & 7 & 4 & 5 & 6 & 3 & $38 \%$ & $14 \%$ & $25 \%$ \\
\hline Totaal & 16172 & 15535 & 14869 & 14450 & 15315 & 14671 & $11 \%$ & $1 \%$ & $1 \%$ \\
\hline
\end{tabular}

De CDM-werkgroep heeft als voorwaarde gesteld dat een melkproductieklasse minimaal 50 bedrijven moet bevatten om een robuust en representatief gemiddelde voor die melkproductieklasse te kunnen vaststellen. Uit Tabel 2.1 blijkt dat de klassen lager dan 3000 en hoger dan 13000 minder dan 50 bedrijven tellen. Daarom beperkt het onderzoek zich tot de range van 3000 tot $13000 \mathrm{~kg}$ melk per koe per jaar.

\footnotetext{
${ }^{2}$ De gebruikte dataset is de ruwe KLW dataset genoemd om onderscheid te maken met de dataset die door de KLW is gecontroleerd en opgeschoond. Door de organisaties betrokken bij de KLW wordt namelijk ook opgeschoond. Bij de onderhavige actualisatie van de excretieforfaits is de opschoning van de dataset heel beperkt gebleven om verlies aan informatie die belangrijk is voor het onderzoek naar de excretieberekening te voorkomen.
} 


\subsubsection{Veestapelniveau versus koeniveau}

De KLW-data is de enige beschikbare bron met sectorbrede praktijkinformatie over het voerverbruik op een melkveebedrijf. De KLW-data hebben betrekking op de gehele veestapel van een bedrijf, d.w.z. melkkoeien, jongvee en eventueel aanwezige andere dieren. De excretieforfaits voor melkkoeien hebben echter betrekking op uitsluitend de melkkoeien.

De te beantwoorden vraag is of er melkproductie-gerelateerde verschillen in het rantsoen zijn die invloed hebben op de excretieberekening van melkkoeien. Als dat het geval is moet per melkproductieklasse met andere relaties gerekend worden bij het vaststellen van excretieforfaits. In de KLW-data is het aantal stuks jongvee per 10 melkkoeien relatief constant over de melkproductieklassen hoger dan ca. $6000 \mathrm{~kg}$ melk per koe per jaar (Figuur 2.1). Door aan te nemen dat de invloed van het jongvee op het rantsoen van het melkvee niet afhankelijk is van het melkproductieniveau, wordt een indruk verkregen van eventuele verschillen in het rantsoen van melkvee tussen melkproductieklassen. Bij controle van de gebruikte trend aan de hand van de KLWdata bleek dat er voor de productieklassen $<6000 \mathrm{~kg}$ melk geen grotere variatie te bestaan dan voor de klassen $>6000 \mathrm{~kg}$ melk.

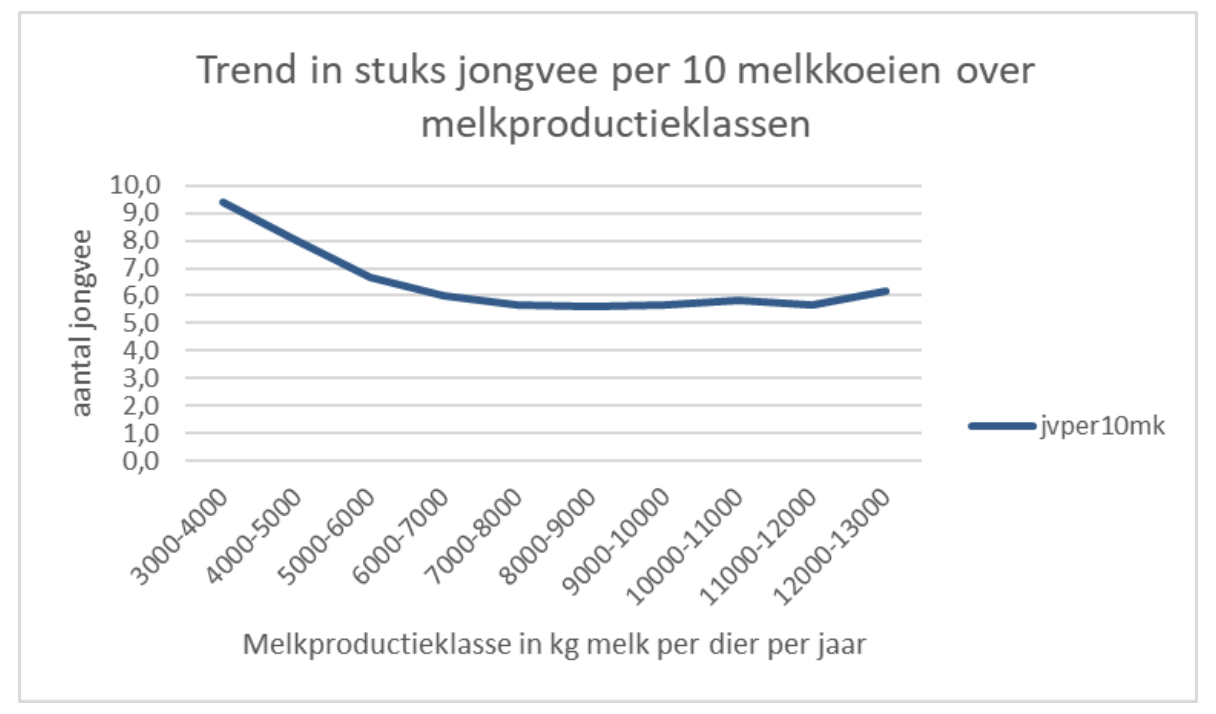

Figuur 2.1 Aantal stuks jongvee per 10 melkkoeien in relatie tot het melkproductieniveau zoals waargenomen in de KLW dataset van 2017, 2018 en 2019.

Voor het vaststellen van de gemiddelde $\mathrm{N}$ - en $\mathrm{P}$-gehalten ${ }^{3}$ in het gevoerde rantsoen geeft het werken op veestapelniveau volgens KLW-data vergelijkbare resultaten als het werken op koeniveau volgens de WUM (Tabel 2.2).

Tabel 2.2 Gemiddelde nationale N- en P-gehalte van het totale rantsoen op koeniveau (WUM, gemiddelde volgens CBS/WUM) en op veestapelniveau ( $K L W$, gemiddelde van $K L W$ ); gemiddelde voor de jaren 2017, 2018 en 2019.

\begin{tabular}{lcc} 
Totale rantsoen & Koeniveau (WUM) & Veestapelniveau (KLW) \\
VEM-gehalte (per kg DS) & 974 & 970 \\
\hline N-gehalte (g / kg DS) & 26,71 & 26,54 \\
\hline P-gehalte (g / kg DS) & 3,68 & 3,61 \\
\hline
\end{tabular}

\footnotetext{
${ }^{3}$ Excreties worden uitgedrukt in $\mathrm{kg}$ fosfaat $\left(\mathrm{P}_{2} \mathrm{O}_{5}\right)$. Gehaltes van fosfor $(\mathrm{P})$ in veevoer, melk en in dieren worden uitgedrukt in $g$ P. Voor de omrekening van fosfor $(P)$ naar fosfaat $\left(\mathrm{P}_{2} \mathrm{O}_{5}\right)$ excretie wordt een factor 2,29 gebruikt.
} 


\subsection{Analyse}

De (beperkt) opgeschoonde dataset is gebruikt om inzicht te krijgen in de vraag of er structurele verschillen bestaan tussen melkproductieklassen voor wat betreft de verbanden tussen melkproductie en de excreties van $\mathrm{N}$ - en $\mathrm{P}_{2} \mathrm{O}_{5}$. Daarvoor is een grafische analyse uitgevoerd van de aan melkproductieniveau gerelateerde trends in de kengetallen van de excretieberekening. In de grafische analyse leiden structurele verschillen tot afwijkingen in een lineair verband.

De bruto excretie of 'excretie onder de staart' voor $\mathrm{N}$ en $\mathrm{P}_{2} \mathrm{O}_{5}$ is daarbij berekend als:

Bruto excretie $(\mathrm{kg} / \mathrm{jaar})=$ opname $(\mathrm{kg} / \mathrm{jaar})$ - vastlegging $(\mathrm{kg} / \mathrm{jaar})$

De kengetallen voor de opname zijn de gebruikte voedermiddelen, de soorten voedermiddelen, de kwaliteit van die voedermiddelen (uitgedrukt als VEM-, N-, P-gehalten en de verhouding VEM/N en VEM/P). De kengetallen voor de vastlegging betreffen de melkproductie en melksamenstelling ( $N-$, Pgehalten). De vastlegging in groei en dracht is als standaardwaarde ingerekend (conform de 'Handreiking bedrijfsspecifieke excretie melkvee' ${ }^{4}$ ) en vertoont daarom geen trends.

\subsection{Trends over melkproductieklassen}

\subsubsection{Algemeen}

Om inzicht te krijgen in trendverschillen tussen melkproductieklassen voor de kengetallen die gebruikt worden bij de excretieberekening zijn de relaties tussen de kengetallen en het melkproductieniveau grafisch weergegeven (Bijlagen 1 en 2). Het betreft een weergave met de kengetallen: aandeel voeders in het rantsoen, gram N en P per kVEM (bijlage 1) en VEM (dimensieloos), gram N en gram $\mathrm{P}$ per kg DS (Bijlage 2). Voor het samenstellen van de grafieken is gewerkt met de KLW-dataset en het betreft gemiddelden over de periode 2017-2019.

\subsubsection{Rantsoenkenmerken}

Het rantsoen van melkkoeien wordt afgestemd op de nutriëntenbehoefte en de opnamecapaciteit van de melkkoeien. De nutriëntenbehoefte wordt voor een belangrijk deel bepaald door het melkproductieniveau. Er zijn verschillende manieren om het nutriëntenaanbod af te stemmen op de melkproductie en het is de vraag of dat in algemene trends resulteert. Bijlage 1 geeft een figuur met de trends in rantsoensamenstelling zoals geobserveerd in de KLW-dataset over 2017, 2018 en 2019. Daaruit blijkt dat er sprake is van duidelijke trends in rantsoenen; bij toenemende melkproductie per koe daalt het aandeel gras (zowel vers gras als graskuil) en stijgt het aandeel krachtvoer en 'overige' producten. Het aandeel snijmaïssilage stijgt tot ca 11000-12000 kg melk per koe en daalt daarna weer naar het niveau bij ca. $10000 \mathrm{~kg}$ melk per dier per jaar. Het totale aandeel ruwvoer in het rantsoen (vers gras, graskuil en snijmaiskuil) daalt gestaag van ca. $83 \%$ bij ca 3500 kg melk per koe naar ca. $58 \%$ bij een melkproductie van ca $12500 \mathrm{~kg}$ per koe (Figuur 2.2).

\footnotetext{
4 RVO (2021) Handreiking bedrijfsspecifieke excretie melkvee. Versie per 14 mei 2021. https://www.rvo.nl/sites/default/files/2021/05/210527-Handreiking-BEX-2021-v1.pdf
} 


\section{Trend in ruwvoeraandeel in het rantsoen over melkproductieklasse}

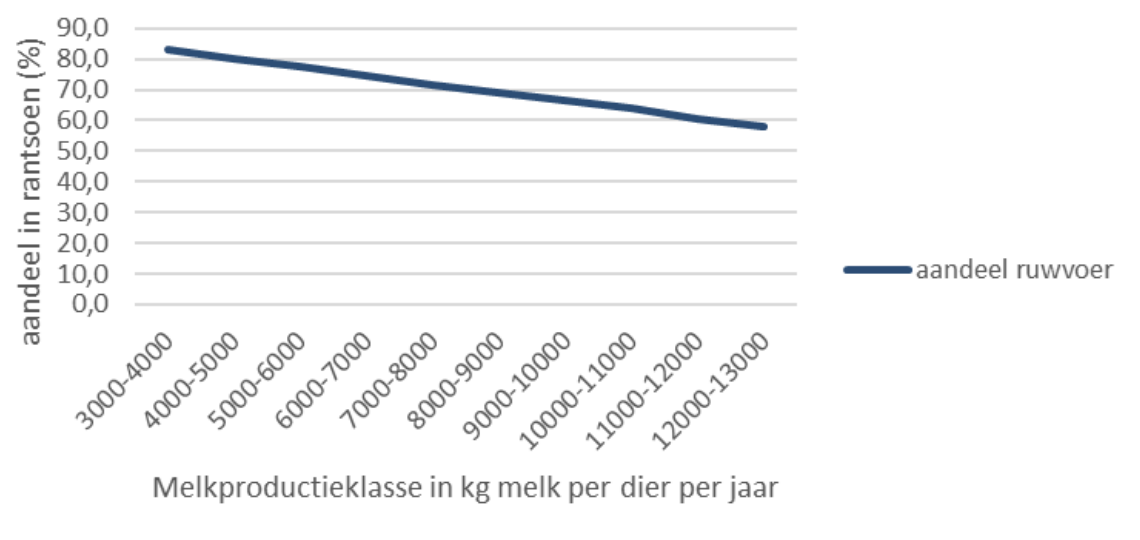

Figuur 2.2 Aandeel ruwvoer (\% in DS ; gras, graskuil en snijmaiskuil) in de KLW-dataset uitgezet tegen melkproductie.

De veranderingen in het rantsoen bij toenemende melkproductie per koe resulteren ook in veranderingen in de hoeveelheid $\mathrm{N}$ en $\mathrm{P}$ per opgenomen kVEM. Bijlage 1 geeft de trend in die verhoudingsgetallen weer als functie van de melkproductieklassen. Uit die bijlage blijkt dat de hoeveelheden stikstof en fosfaat per opgenomen kVEM afnemen bij toenemende melkproductie per koe.

\subsubsection{Kwaliteit van het rantsoen}

De kwaliteit van het rantsoen wordt in dit verband uitgedrukt in het VEM-, $\mathrm{N}$ - en P-gehalten per kg droge stof (DS) van het rantsoen. Voor de KLW-dataset zijn eventuele trends in het VEM-, N- en Pgehalten per kg DS van het rantsoen onderzocht door het VEM-, N- en P-gehalte uit te zetten tegen de melkproductieklassen (Bijlage 2). Voor het traject van 3000 tot $13000 \mathrm{~kg}$ melk per koe per jaar neemt het VEM-gehalte per kg DS rantsoen toe met bijna 10\%, van ongeveer 925 tot 1005 VEM per kg DS. Deze toename verloopt vrijwel lineair met het melkproductieniveau.

Het N-gehalte per kg DS neemt ook toe over de genoemde melkproductierange, met bijna $6 \%$ van ongeveer 25,5 tot 27,0 g N per kg DS. Deze toename is duidelijk zichtbaar, maar het $\mathrm{N}$-gehalte per kg DS in de melkproductierange van ongeveer $6000-11000 \mathrm{~kg}$ is vrijwel constant (ongeveer 26,5 g N per kg DS).

Het P-gehalte van het rantsoen laat - na een initiële verhoging in de klasse 4000-5000 - een dalende trend zien tot ca. $11000 \mathrm{~kg}$ melk per koe per jaar, waarbij het gehalte afneemt van ongeveer 3,65 naar 3,55 g P/kg DS. Vervolgens neemt het P-gehalte weer toe tot net boven de 3,65 g P/kg DS bij ca. $13000 \mathrm{~kg}$ melk. Voor de klasse 4000-5000 is in de onderliggende data een afwijkend hoge waarde voor 2017 geconstateerd en in mindere mate ook voor 2018, maar in 2019 vertoont deze melkproductieklasse geen afwijking van de trendlijn.

\subsubsection{Opname, vastlegging en excretie}

Hoe de trends in voerkwaliteit doorwerken in de $\mathrm{N}$ - en $\mathrm{P}_{2} \mathrm{O}_{5}$-excreties is afhankelijk van de voeropname. De voeropname door melkkoeien is niet beschikbaar in de KLW; daarom is door de 'CDM-werkgroep excretieforfaits' de voeropname berekend op basis van de VEM-behoefte van de melkkoeien. Dat is gedaan door de berekende VEM-behoefte te delen door het in de KLW-dataset geobserveerde VEM-gehalte van het rantsoen (per kg DS). Dat geeft de voeropname in $\mathrm{kg}$ DS. Vervolgens is de $\mathrm{N}$ - en $\mathrm{P}$-opname van de melkkoeien berekend met het geobserveerde $\mathrm{N}$ - en $\mathrm{P}$ gehalten, in gram per kg DS. Trends in de opname, vastlegging en excretie als functie van melkproductie zijn inzichtelijk gemaakt in de Figuren 2.3 (voor N) en 2.4 (voor P). 


\section{Trend N-opname, N-vastlegging en $\mathrm{N}$-excretie over melkproductieklassen}

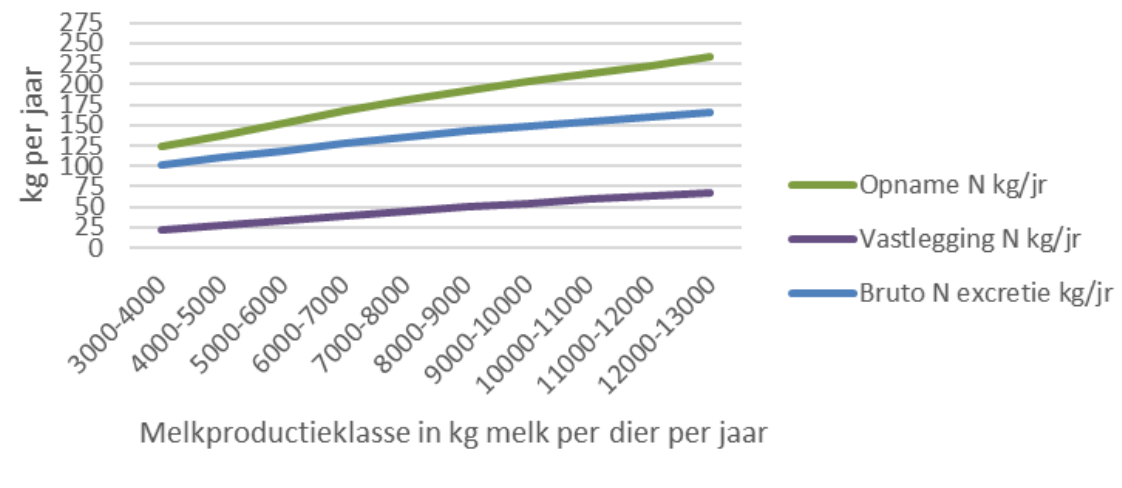

Figuur 2.3 Trends in berekende $\mathrm{N}$-opname, $\mathrm{N}$-vastlegging en bruto $\mathrm{N}$-excretie ( $\mathrm{kg}$ per koe per jaar) als functie van melkproductieklasse. Bruto $N$ - excretie is de excretie 'onder de staart' zonder aftrek van gasvormige verliezen.

Figuur 2.3 laat zien dat op basis van KLW-data zowel de N-opname als de $\mathrm{N}$-vastlegging een trend vertonen van toename bij toenemende melkproductie. De $\mathrm{N}$-excretie (het verschil tussen $\mathrm{N}$-opname en $\mathrm{N}$-vastlegging) kent daarmee eenzelfde trend als die van de $\mathrm{N}$-opname en de $\mathrm{N}$-vastlegging. Deze trend is lineair voor melkproducties van 3000-13000 kg per koe per jaar.

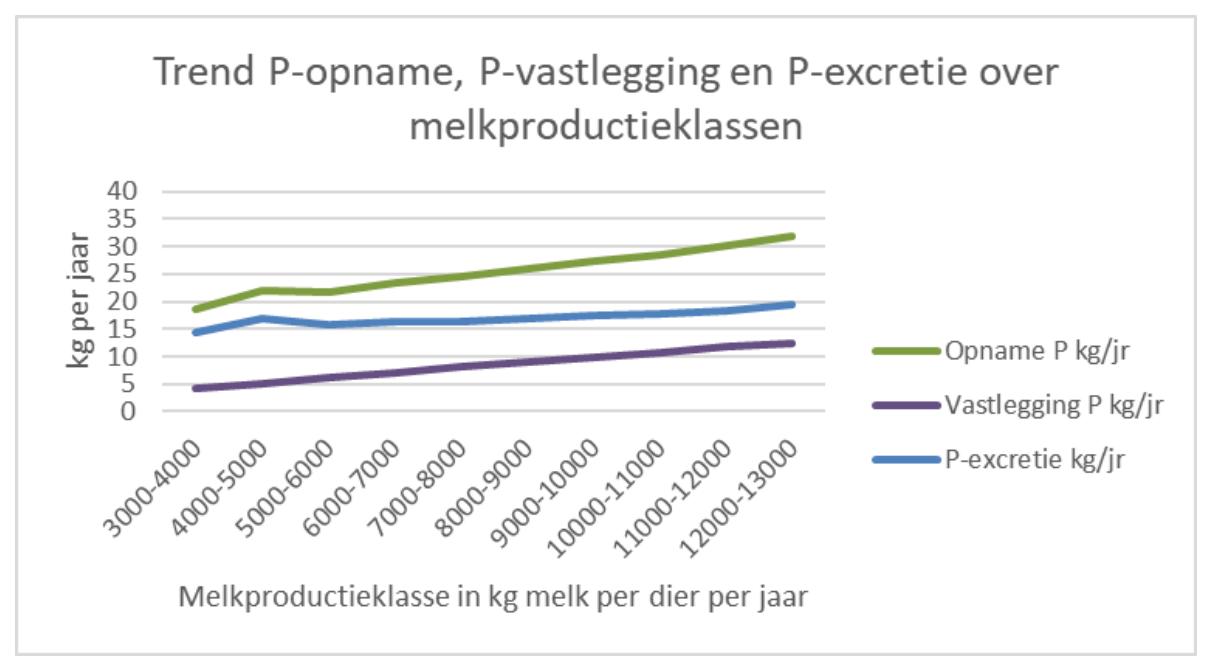

Figuur 2.4 Trends in berekende P-opname, P-vastlegging en P-excretie ( $k g$ per koe per jaar) als functie van melkproductieklasse.

Figuur 2.4 laat zien dat op basis van KLW-data de trends voor de P-opname en P-vastlegging globaal vergelijkbaar zijn met die voor $\mathrm{N}$, maar dat de opname in relatieve zin minder snel stijgt dan de vastlegging. Hierdoor stijgt de $\mathrm{P}$-excretie minder snel met het melkproductieniveau dan de $\mathrm{N}$-excretie. Globaal is ook voor P-excretie de trend lineair voor melkproducties van 3000-13000 kg per koe per jaar. 


\subsubsection{KLW excretie versus excretie volgens de huidige schattingsformules}

De bruto $\mathrm{N}$-excretie ${ }^{5}$ (= 'onder de staart' d.w.z. zonder aftrek van gasvormige verliezen) en de $\mathrm{P}_{2} \mathrm{O}_{5}-$ excretie per melkkoe zijn in de vorige paragraaf berekend op basis van de KLW dataset met de balansmethode (excretie = opname - vastlegging). Dit verschilt van de oorspronkelijk berekeningsmethode van de excretieforfaits, waarbij gerekend wordt met schattingsformules. Deze schattingsformules geven de excretie als functie van de bedrijfsgemiddelde melkproductie per koe, die voor stikstof wordt aangevuld met het bedrijfsgemiddelde ureumgehalte in de melk (Bikker et al, 2019). Daarbij wordt de gemiddelde N-excretie (volgens WUM) gedifferentieerd naar de over drie jaren gemiddelde melkproductie per koe en het ureumgehalte in de melk (volgens CBS):

1. Bruto $\mathrm{N}$-excretie in $\mathrm{kg}$ per dier per jaar $=$

Gemiddelde N-excretie WUM + 0,0094* (Melkproductie bedrijf - gemiddelde melkproductie CBS) $+1,8 *$ (Melkureum bedrijf - gemiddelde melkureum CBS)

Voor fosfaat wordt de gemiddelde $\mathrm{P}_{2} \mathrm{O}_{5}$-excretie (volgens WUM) gedifferentieerd naar de over drie jaren gemiddelde melkproductie per koe (volgens CBS):

2. $\mathrm{P}_{2} \mathrm{O}_{5}$-excretie in $\mathrm{kg}$ per dier per jaar $=$

Gemiddelde $\mathrm{P}_{2} \mathrm{O}_{5}$-excretie WUM $+0,0029 *$ (Melkproductie bedrijf - gemiddelde melkproductie CBS)

Met bovenstaande formules, gebruikt voor het afleiden van de huidige forfaits, is ook de gemiddelde bruto excretie voor melkkoeien berekend over de jaren 2017, 2018 en 2019. Dat is gedaan door voor de in te vullen gemiddelde melkproductie per koe, het gemiddelde ureumgehalte in de melk en de gemiddelde bruto $\mathrm{N}$ - en $\mathrm{P}_{2} \mathrm{O}_{5}$-excreties per koe, de gemiddelde CBS/WUM-waarden over 2017, 2018 en 2019 te gebruiken:

Gemiddelde melkproductie (CBS):

Gemiddeld N-excretie (WUM):

Gemiddeld $\mathrm{P}_{2} \mathrm{O}_{5}$-excretie (WUM):

Gemiddelde melkureum (CBS):
$8797 \mathrm{~kg}$ per dier per jaar

$145,6 \mathrm{~kg}$ per dier per jaar

$40,57 \mathrm{~kg}$ per dier per jaar

$22,54 \mathrm{mg} / 100 \mathrm{~g}$ melk

Vervolgens is gekeken of de excreties berekend met bovenstaande schattingsformules passen bij de excreties afgeleid uit de KLW-dataset 2017, 2018 en 2019 (zie paragraaf 2.3.4).

In Figuur 2.5 is voor zowel de $\mathrm{N}$-excreties als voor de $\mathrm{P}_{2} \mathrm{O}_{5}$-excreties het verschil weergegeven tussen de bruto-excretie berekend met formules 1 en 2 en zoals afgeleid uit de KLW-data (gemiddelden over 2017, 2018 en 2019). Bij de berekening van de excreties zijn de formules 1 en 2 'gevuld' met de WUM gemiddelden over 2017, 2018 en 2019.

\footnotetext{
${ }^{5}$ Het excretieforfait voor stikstof (= netto N-excretie) wordt berekend door de bruto N-excretie te verminderen met gasvormige $\mathrm{N}$-verliezen die optreden in de stal en bij mestopslag buiten de stal (zogenoemde stikstofcorrectiefactor). Daarbij wordt onderscheid gemaakt tussen drijfmest en vaste mest, omdat er onderscheidenlijke stikstofverliezen optreden bij de opslag van drijfmest en vaste mest in stal en mestopslag. Voor fosfaat $\left(\mathrm{P}_{2} \mathrm{O}_{5}\right)$ is er geen correctie, omdat er geen gasvormige fosfaatverliezen optreden.
} 


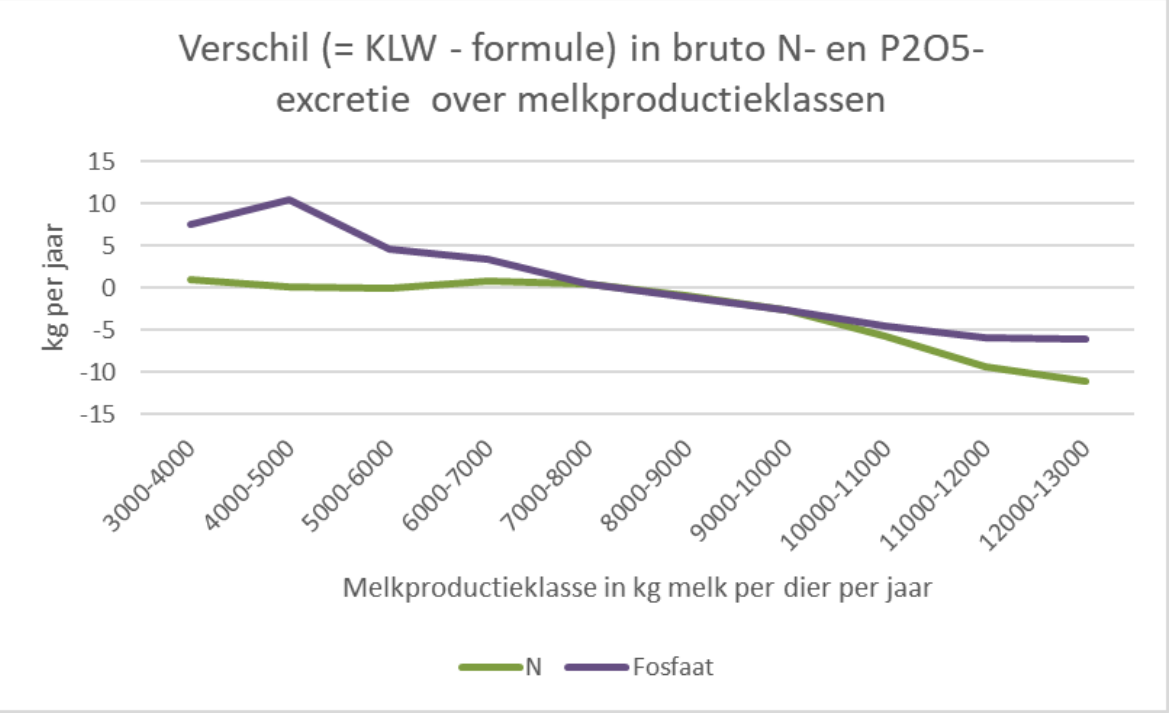

Figuur 2.5 Verschillen tussen de $\mathrm{N}$ - en $\mathrm{P}_{2} \mathrm{O}_{5}$-excreties afgeleid uit $K L W$-data en die afgeleid van de schattingsformules (formules 1 en 2) voor $\mathrm{N}$ - en $\mathrm{P}_{2} \mathrm{O}_{5}$-excreties volgens Bikker et al (2019) in kg per koe per jaar, als functie van melkproductieklasse. Bij geen verschil zouden de lijnen voor stikstof en fosfaat horizontaal op de 0-lijn hebben gelegen.

Figuur 2.5 laat zien dat bij toenemende melkproducties vanaf ca. $7500 \mathrm{~kg}$ melk het verschil toeneemt tussen de $\mathrm{N}$ - en $\mathrm{P}_{2} \mathrm{O}_{5}$-excreties berekend op basis van de $\mathrm{KLW}$-data en die berekend op basis van de schattingsformules waarop de huidige excretie forfaits zijn gebaseerd (Bikker et al, 2019). Voor de Nexcretie komen de schattingsformules en de berekende KLW-excretie goed overeen in het traject van 3000 tot ca. $7500 \mathrm{~kg}$ melk per koe per jaar. Daarna lopen de verschillen op tot ca. 6\% overschatting door de formules. Voor de $\mathrm{P}_{2} \mathrm{O}_{5}$-excretie zijn de relatieve verschillen groter dan voor $\mathrm{N}$ en is sprake van kruisende lijnen, zodat er zowel onder als boven het snijpunt bij ca. 7000 kg melk per koe sprake is van toenemende verschillen. Voor melkproducties $<7000 \mathrm{~kg}$ per koe geven de formules een te lage fosfaatexcretie (toenemend tot ca $-23 \%$ ) en voor melkproductie $>7000 \mathrm{~kg}$ een te hoge excretie (toenemend tot ca. $+13 \%$ ).

De verschillen in Figuur 2.5 geven aan dat de resultaten van de schattingsformules, waarop de huidige forfaits voor de $\mathrm{N}$ - en $\mathrm{P}_{2} \mathrm{O}_{5}$-excreties van melkkoeien zijn gebaseerd, niet overeenkomen met de resultaten van de KLW-dataset van 2017, 2018 en 2019. Bij gemiddelde melkproducties van 7000 tot $9000 \mathrm{~kg}$ per koe zijn de verschillen verwaarloosbaar klein, maar bij relatief lage melkproducties per koe geven de schattingsformules te lage $\mathrm{P}_{2} \mathrm{O}_{5}$-excreties en bij relatief hoge melkproducties geven de schattingsformules te hoge $\mathrm{N}$ - en $\mathrm{P}_{2} \mathrm{O}_{5}$-excreties.

\section{$2.4 \quad$ Conclusies}

- De beschikbare KLW-dataset voor 2017, 2018 en 2019 bevat, na beperkte opschoning, gemiddeld 14812 bedrijven per jaar, waarvan er ca. 20 bedrijven minder dan $3000 \mathrm{~kg}$ melk en ca. 10 bedrijven meer dan $13000 \mathrm{~kg}$ melk per koe per jaar produceren. Deze dataset omvat ca. 95\% van Nederlandse melkbedrijven.

- In het traject van 3000 tot $13000 \mathrm{~kg}$ melk per dier per jaar komen minimaal 50 bedrijven per klasse van $1000 \mathrm{~kg}$ melk voor. Er is aangenomen dat bij minimaal 50 bedrijven per klasse de invloed van één of enkele afwijkende bedrijven op het gemiddelde van die klasse gering is. Daarmee is de dataset geschikt om conclusies te trekken in het traject van 3000 tot $13000 \mathrm{~kg}$ melk per dier per jaar. 
- In het traject van 3000-13000 kg melk per jaar zijn over melkproductieklassen heen duidelijke trends waargenomen in rantsoensamenstelling, de nutriëntendichtheid van het rantsoen, de $\mathrm{N}$ en $\mathrm{P}$-opname en de $\mathrm{N}$ - en $\mathrm{P}$-excreties per koe per jaar. De gevonden verbanden zijn nagenoeg lineair en consistent over het hele traject van beschikbare melkproductieklassen. Op basis daarvan wordt geconcludeerd dat de methodiek onder de huidige forfaits, namelijk het werken met lineaire verbanden, niet aangepast hoeft te worden.

- De beschikbare KLW-dataset voor 2017, 2018 en 2019 laat zien dat het aantal stuks jongvee per 10 melkkoeien vrijwel constant is voor de melkproductieklassen van ca. $6000 \mathrm{~kg}$ per jaar en hoger. Daarom is verondersteld dat voor die range de gevonden relaties op veestapelniveau ook representatief zijn voor melkkoeien (= de doelgroep). Voor melkproducties $<6000 \mathrm{~kg}$ melk neemt het aantal jongvee echter toe en zou een fout gemaakt kunnen worden, maar die fout speelt geen relevante rol gezien de geobserveerde consistente trendlijnen van 3000-13000 kg melk.

- $\quad$ Over het melkproductietraject van 3000-13000 kg melk per jaar verschillen de excreties berekend met de schattingsformules waarop de forfaits zijn gebaseerd van de excreties berekend op basis van de KLW-dataset. De grootte van de verschillen varieert met het melkproductieniveau. Voor $\mathrm{N}$ zijn de verschillen maximaal $6 \%$ en voor fosfaat maximaal $23 \%$. Op basis van het 'melkproductieniveau variërend verschil' wordt geconcludeerd dat de schattingsformules een update behoeven. 


\section{Aanpassen berekening forfaitaire excretie}

\subsection{Algemeen}

In paragraaf 2.4 is geconcludeerd dat het verband tussen excretie en melkproductie lineair is voor de melkproductierange van 3000 tot $13000 \mathrm{~kg}$ melk per koe. Daarmee is tevens aannemelijk gemaakt dat het lineaire verband dat gebruikt wordt in de huidige schattingsformules voor de berekening van de $\mathrm{N}$ - en $\mathrm{P}_{2} \mathrm{O}_{5}$-excreties kan worden gehandhaafd voor de betreffende melkproductierange.

In paragraaf 2.4 is ook geconcludeerd dat er een verschil bestaat tussen de excreties afgeleid van de KLW-dataset en de excreties afgeleid met schattingsformules waarop de huidige excretieforfaits zijn gebaseerd (Bikker et al., 2019). Dat verschil (weergeven in procenten, Figuur 3.1) is afhankelijk van het melkproductieniveau en duidt er op dat de huidige schattingsformules niet meer goed passen bij de actuele relatie tussen excretie en melkproductie. Dit is vooral voor fosfaat aan de orde.

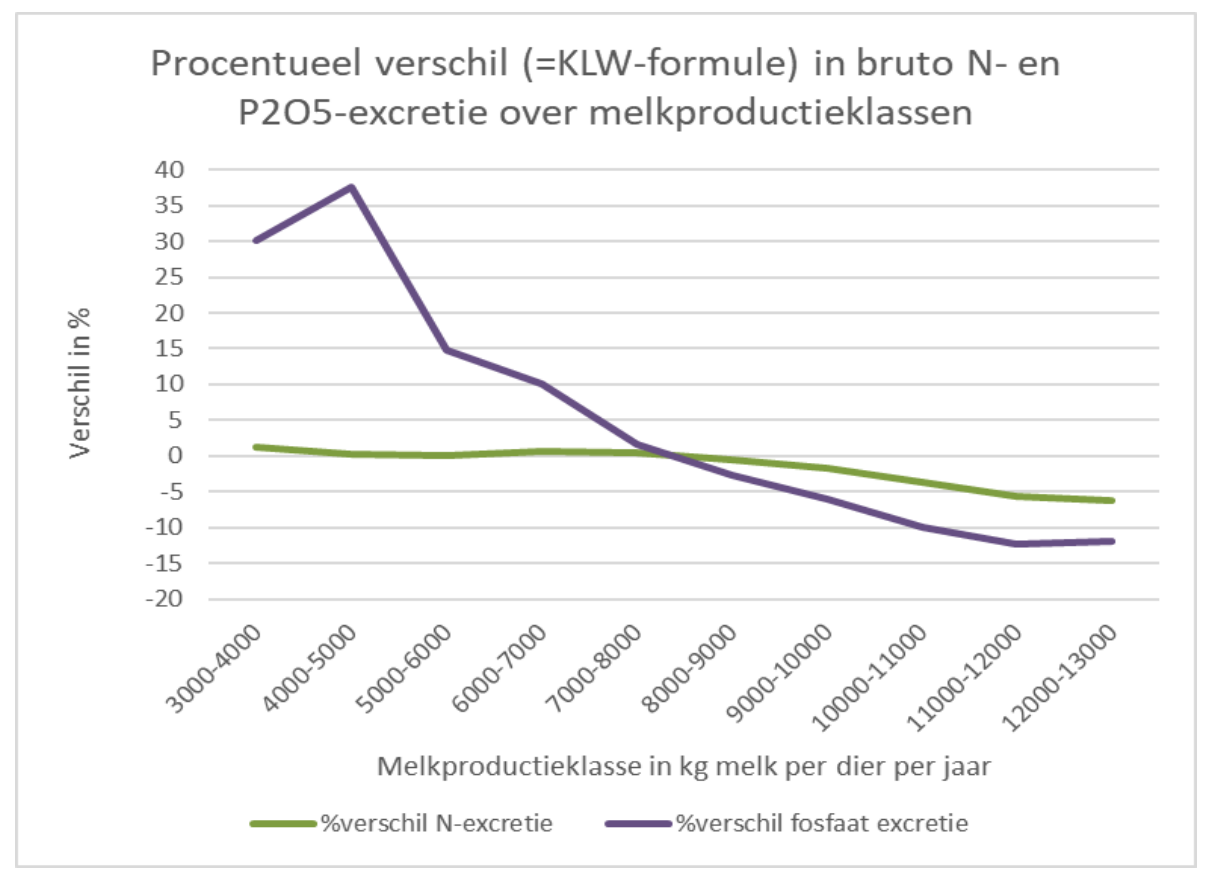

Figuur 3.1 Verschillen (\%, $100 \times$ verschil/excretie schattingsformule) tussen de resultaten afgeleid uit $\mathrm{KLW}$-data en die van de schattingsformules voor $\mathrm{N}$ - en $\mathrm{P}_{2} \mathrm{O}_{5}$-excreties (Bikker et al, 2019) als functie van melkproductieklasse. Bij geen verschil zouden de lijnen voor stikstof en fosfaat horizontaal op de 0 -lijn hebben gelegen. Deze figuur komt overeen met Figuur 2.5, maar het verschil op de $Y$-as is nu uitgedrukt in \%.

Uit figuur 3.1. blijkt dat voor $\mathrm{P}_{2} \mathrm{O}_{5}$-excreties het verschil tussen de resultaten van de huidige schattingsformules en die van de KLW-data in het meest extreme geval oploopt tot ca. 30\% (de waarneming in melkproductieklasse $4000-5000 \mathrm{~kg}$ is atypisch). Voor $\mathrm{N}$-excreties is dat verschil maximaal 6\%. De schattingsformules van de huidige forfaits (Bikker et al, 2019) zijn afgeleid op basis van experimentele data uit de periode 1990 tot 2005. De melkveehouderij heeft sindsdien flinke veranderingen ondergaan in melkproductieniveau, efficiëntie van de $\mathrm{N}$ - en P-benutting, gevoerde rantsoenen en het excretieniveau per kg melk. Dat is het argument om de schattingsformules aan te passen. 


\subsection{Aanpassing van de schattingsformules}

\subsubsection{Samenstelling schattingsformules}

De schattingsformules voor de bruto $\mathrm{N}$ - en $\mathrm{P}_{2} \mathrm{O}_{5}$-excreties zijn 'geijkt' op de gemiddelde $\mathrm{N}$ - en $\mathrm{P}_{2} \mathrm{O}_{5}$ excreties in Nederland (volgens WUM) en vervolgens gedifferentieerd naar melkproductie en melkureumgehalte (voor $\mathrm{N}$-excreties) en naar melkproductie (voor $\mathrm{P}_{2} \mathrm{O}_{5}$-excreties). Voor dat differentiëren wordt gebruik gemaakt van de relaties tussen $\mathrm{N}$ - en $\mathrm{P}_{2} \mathrm{O}_{5}$-excreties en het melkproductieniveau en (voor $\mathrm{N}$ ook) het melkureumgehalte. De schattingsformules zien er als volgt uit:

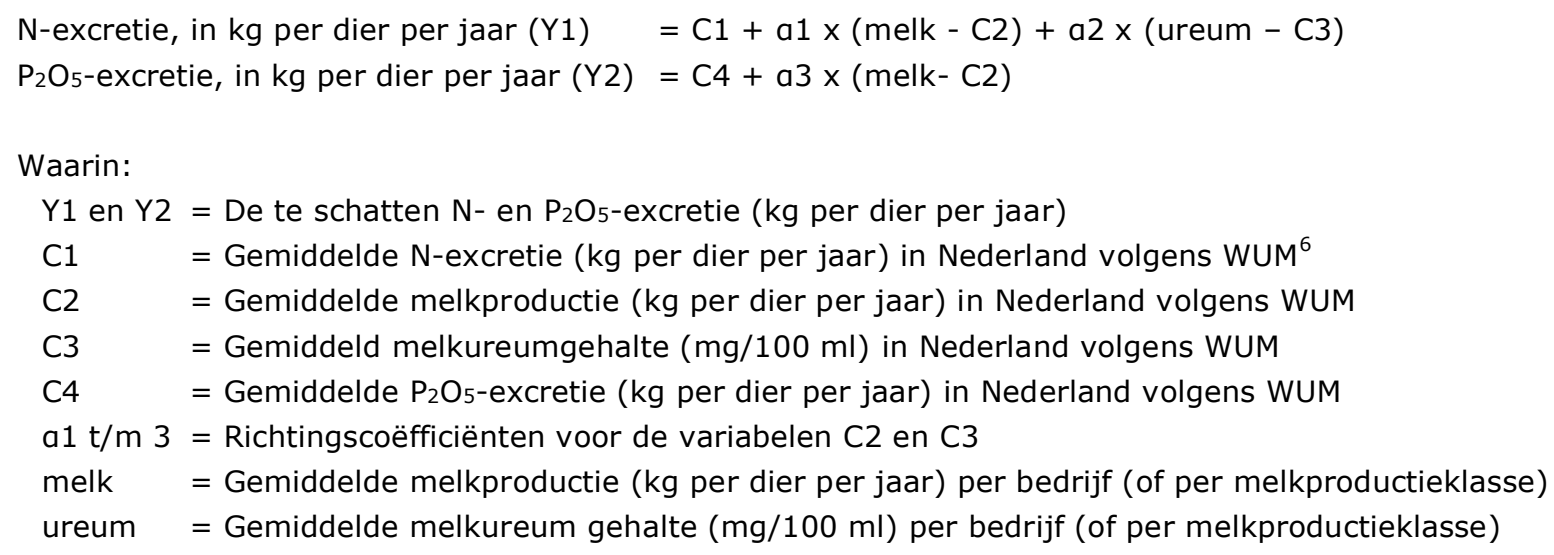

Uit de bovenstaande formules blijkt dat een aanpassing van de schattingsformules neerkomt op het aanpassen van de richtingscoëfficiënten a $1 \mathrm{t} / \mathrm{m}$ a3. In de schattingsformules die gebruikt zijn voor de huidige forfaits zijn de richtingscoëfficiënten: $a 1=0,0094 ; a 2=1,8 ; a 3=0,0029$ (Bikker et al, 2019). De relatie tussen de $\mathrm{N}$-excretie en het melkureumgehalte is niet gewijzigd ten opzichte van de vorige update van de excretieforfaits, zodat de richtingscoëfficiënt $\alpha 2$ ongewijzigd blijft.

\subsubsection{Werkwijze}

Voor het afleiden van de richtingscoëfficiënten van de relaties tussen melkproductie en $\mathrm{N}$ - en $\mathrm{P}_{2} \mathrm{O}_{5}$ excreties zijn data nodig waarmee de $\mathrm{N}$ - en $\mathrm{P}_{2} \mathrm{O}_{5}$-excreties kunnen worden vastgesteld, over de melkproductierange. Voor het berekenen van de excreties zijn de volgende data nodig:

- De melkproductie (in kg FPCM) en het diergewicht (in $\mathrm{kg}$ ), voor de berekening van de VEMbehoefte voor onderhoud en melkproductie. Voor groei, arbeid en de negatieve energiebalans (NEB) worden vaste VEM-toeslagen gebruikt.

- $\quad$ De VEM/N en VEM/P verhoudingen in het totale rantsoen, om op basis van de VEM-behoefte de $\mathrm{N}$ - en P-opname te kunnen berekenen.

- De melkproductie en melksamenstelling, om de $\mathrm{N}$ - en P-vastlegging in melk te berekenen. Voor de vastlegging van $\mathrm{N}$ en $\mathrm{P}$ in lichaamsweefsel zijn vaste waarden gebruikt.

De VEM-behoefte voor onderhoud en melkproductie is berekend volgens de geldende CVB-rekenregels (CVB, 2016). Dat geldt ook voor de toeslagen voor VEM-behoefte, zodat de gebruikte vaste VEMtoeslagen (voor groei, arbeid en NEB) en voor de vastlegging van N en $\mathrm{P}$ in lichaamsweefsel ook overeen komen met die van de 'Handreiking bedrijfsspecifieke excretie melkvee'.

\footnotetext{
${ }^{6}$ Voor dit rapport betreft het de WUM gemiddelden over de jaren 2017, 2018 en 2019.
} 
Verder zijn de volgende veranderingen doorgevoerd in de berekeningen:

- De melkproductierange waarvoor de formules gelden is uitgebreid van 5625 - 10624 naar 2874 - $13124 \mathrm{~kg}$ melk per koe per jaar. Dit is gebeurd op basis van de bevindingen in hoofdstuk 2 van dit rapport.

- $\quad$ De VEM/N en VEM/P verhoudingen in het totale rantsoen zijn per melkproductieklasse van de $\mathrm{KLW}$-data afgeleid (zie volgende paragraaf). Met deze werkwijze wordt rekening gehouden met de verschillen in de samenstelling van het rantsoen die samenhangen met het melkproductieniveau.

- Voor beweiding is de VEM-toeslag berekend per melkproductieklasse van $1000 \mathrm{~kg}$ melk op basis van de opgegeven dagen weiden (beperkt en/of onbeperkt) in de KLW-dataset van 2017, 2018 en 2019.

\subsubsection{Vaststellen specifiek rantsoen per melkproductieklasse}

De gebruikte KLW-dataset over 2017, 2018 en 2019 bevat ruwe data die alleen gescreend zijn op negatieve waarden voor kengetallen die bij de excretieberekening gebruikt worden en die per definitie positief moeten zijn. Er is dus niet gecheckt of de overige data logischerwijs plausibel zijn. In de dataset kunnen daarom uitbijters voorkomen die de te onderzoeken relaties verstoren. Dit kan resulteren in een ongelijke verdeling van de puntenwolk, bijvoorbeeld doordat aan 1 kant een natuurlijke grens ligt (in dit geval de ondergrens omdat de data niet kleiner dan nul kunnen zijn). Figuur 3.3 toont voor de KLW dataset de variaties in berekende $\mathrm{N}$ - en $\mathrm{P}_{2} \mathrm{O}_{5}$-excreties uitgezet tegen de melkproductie. De variaties zijn grotendeels het gevolg van variaties in de geregistreerde rantsoenen.
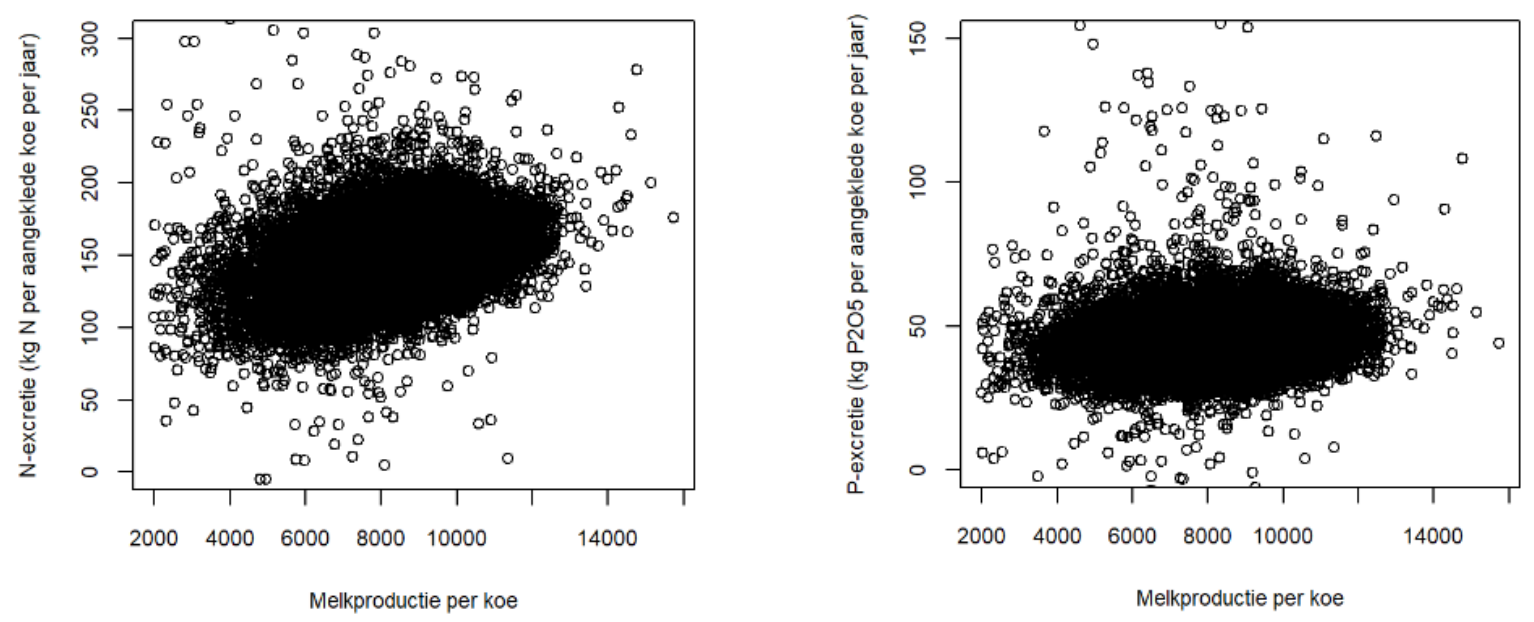

Figuur 3.3 Variaties in $\mathrm{N}$ - en $\mathrm{P}_{2} \mathrm{O}_{5}$-excreties per melkkoe plus bijbehorend jongvee (aangeduid als 'aangeklede koe'), als functie van de melkproductie per koe (in $\mathrm{kg}$ melk per koe per jaar). Links: $\mathrm{N}$-excreties, rechts: $\mathrm{P}_{2} \mathrm{O}_{5}$-excreties (Bron: $\mathrm{KLW}$ dataset).

Uit Figuur 3.3 blijkt dat de puntenwolk voor de excreties een 'sigaarvorm' hebben waarin een trendlijn getrokken kan worden. Echter, er zijn ook relatief veel punten die afwijken van die trendlijn, en wellicht is het nodig om te werken op basis van de mediane in plaats van de gemiddelde $\mathrm{N}-$ en $\mathrm{P}_{2} \mathrm{O}_{5}-$ excreties. Om dat te onderzoeken zijn zowel de gemiddelde als de mediane $\mathrm{N}$ - en $\mathrm{P}_{2} \mathrm{O}_{5}$-excreties per melkproductieklasse van $1000 \mathrm{~kg}$ vastgesteld voor de KLW dataset. Vervolgens is de trendlijn tussen excretie en melkproductie gefit voor zowel de gemiddelde als de mediane $\mathrm{N}$ - en $\mathrm{P}_{2} \mathrm{O}_{5}$-excreties (Tabel 3.1). De $R^{2}$ geeft aan in welke mate de verklarende variabele (=melkproductie) de geobserveerde variantie in de excretie $(Y)$ verklaart. Door de $R^{2}$ van de trendlijnen op basis van gemiddelden en medianen te vergelijken kan de keuze voor het gebruik van het gemiddelde of de mediaan onderbouwd worden. 
Tabel 3.1 Trendlijnen $(Y=C+\alpha X)$ voor de relaties tussen $\mathrm{N}$ - en $\mathrm{P}_{2} \mathrm{O}_{5}$-excreties $(Y, \mathrm{~kg}$ per koe per jaar) en melkproductie ( $X, 1000 \mathrm{~kg}$ per koe per jaar) in de range van $3000-13000 \mathrm{~kg}$, met richtingscoëfficiënt $\alpha$. De trendlijnen zijn gebaseerd op KLW-data van 2017, 2018 en 2019 die zijn vastgesteld als gemiddelde en mediaan per melkproductieklasse van 1000 kg per koe per jaar.

\begin{tabular}{lcccc} 
& & $\mathrm{C}$ & $\mathrm{a}$ & $\mathrm{R}^{2}$ \\
Gemiddelden & $\mathrm{N}$-excretie $(\mathrm{kg} / \mathrm{koe} / \mathrm{jaar})$ & 98,0 & 7,02 & 0,99 \\
\hline & $\mathrm{P}_{2} \mathrm{O}_{5}$-excretie $(\mathrm{kg} / \mathrm{koe} /$ jaar) & 33,6 & 0,96 & 0,81 \\
\hline & & & & \\
\hline Medianen & $\mathrm{N}$-excretie (kg / jaar) & 94,6 & 7,46 & 0,99 \\
\hline & $\mathrm{P}_{2} \mathrm{O}_{5}$-excretie (kg / jaar) & 29,6 & 1,43 & 0,98 \\
\hline
\end{tabular}

Tabel 3.1 laat zien dat voor fosfaat de trendlijn op basis van de gemiddelden per melkproductieklasse een matige verklaring geeft voor de geobserveerde variantie $\left(R^{2}=0,81\right)$ en dat de variantie uitstekend wordt verklaard $\left(R^{2}=0,98\right)$ door de trendlijn op basis van de medianen per melkproductieklasse. Daaruit blijkt dat er voor de $\mathrm{P}_{2} \mathrm{O}_{5}$-excreties in de $\mathrm{KLW}$ dataset niet alleen veel variatie voorkomt, maar dat er ook relatief veel waarnemingen zijn die het gemiddelde beïnvloeden. Daarom is voor de update van de richtingscoëfficiënt van de formules waarmee de forfaits worden berekend met de medianen gewerkt. Omwille van consistentie is dat ook gedaan voor de N-excretie, hoewel uit Tabel 3.1 blijkt dat dit niet noodzakelijk is.

\subsubsection{Update richtingscoëfficiënten schattingsformules}

Voor de update van de richtingscoëfficiënten van de schattingsformules voor de $\mathrm{N}$ - en $\mathrm{P}_{2} \mathrm{O}_{5}$-excreties is gebruikt gemaakt van gemiddelden van de Nederlandse melkveestapel zoals vastgesteld door WUM (zie paragraaf 3.2.1). Om de $\mathrm{N}$ - en P-opname goed te kunnen berekenen is per melkproductieklasse van $1000 \mathrm{~kg}$ het gemiddelde rantsoen vastgesteld op basis van de medianen in de KLW dataset (conform vorige paragraaf). Vervolgens zijn per melkproductieklasse de gemiddelde $\mathrm{N}$ - en $\mathrm{P}_{2} \mathrm{O}_{5}$ excreties berekend, waarna de trendlijnen van de relaties tussen excreties en melkproductie zijn gefit (grafische weergave in Bijlage 3). De richtingscoëfficiënten van deze trendlijnen (Tabel 3.2) zijn de coëfficiënten van de schattingsformules voor het afleiden van de (forfaitaire) $\mathrm{N}$ - en $\mathrm{P}_{2} \mathrm{O}_{5}$-excreties per melkproductieklasse.

Tabel 3.2 Trendlijnen $(Y=C+\alpha X)$ met richtingscoëfficiënt $\alpha$, voor de relaties tussen $\mathrm{N}$ - en $\mathrm{P}_{2} \mathrm{O}_{5}$ excreties ( $Y, \mathrm{~kg} / \mathrm{koe} / \mathrm{jaar}$ ) en melkproductie ( $X, \mathrm{~kg} / \mathrm{koe} / \mathrm{jaar}$ ) in de range van 3000 $13000 \mathrm{~kg}$. De trendlijnen zijn gebaseerd op WUM data en KLW-data uit 2017, 2018 en 2019 (zie tekst).

\begin{tabular}{lcccc} 
Y & $\mathrm{C}$ & a & $\mathrm{R}^{2}$ \\
$\mathrm{~N}$-excretie (kg / koe / jaar) & 92,4 & 0,0079365 & 0,99 \\
\hline $\mathrm{P}_{2} \mathrm{O}_{5}$-excretie (kg / koe / jaar) & 28,9 & 0,0015533 & 0,97 \\
\hline
\end{tabular}

De resultaten in Tabel 3.2 geven de volgende nieuwe schattingsformules:

$\mathrm{N}$-excretie, in kg per koe per jaar $=145,6+0,0079365 \times($ melk -8797$)+1,8 \times($ ureum $-22,5)$ $\mathrm{P}_{2} \mathrm{O}_{5}$-excretie, in kg per koe per jaar $=40,6+0,0015533 \times($ melk -8797$)$

In deze formules is 145,6 de gemiddelde $\mathrm{N}$-excretie ( $\mathrm{kg}$ per dier per jaar) in Nederland volgens WUM; 8797 is de gemiddelde melkproductie (kg per dier per jaar) in Nederland volgens WUM; 22,5 is het gemiddelde melkureumgehalte $(\mathrm{mg} / 100 \mathrm{ml}$ ) in Nederland volgens WUM; en 40,6 is de gemiddelde $\mathrm{P}_{2} \mathrm{O}_{5}$-excretie (kg per dier per jaar) in Nederland volgens WUM over de jaren 2017, 2018 en 2019. 


\subsection{Conclusies}

- $\quad$ De verbanden tussen melkproductie en $\mathrm{P}_{2} \mathrm{O}_{5}$-excretie en tussen melkproductie plus melkureum en $\mathrm{N}$-excretie zijn veranderd in de voorbije jaren, en ten opzichte van eerdere actualisaties van de excretieforfaits. Daardoor zijn de richtingscoëfficiënten van de verbanden gewijzigd. De richtingscoëfficiënt reageert op veranderingen in de melkveehouderij; deze veranderingen hebben vooral betrekking op de gevoerde rantsoenen en de efficiëntie van de benutting van $\mathrm{N}$ en $P$ in het voer door melkkoeien.

- Nieuwe richtingscoëfficiënten voor de schattingsformules voor de berekening van de $\mathrm{N}$ - en $\mathrm{P}_{2} \mathrm{O}_{5}$ excreties zijn afgeleid op basis van nationale gemiddelden (WUM) voor melkproductie en melksamenstelling, en op basis van rantsoenen per melkproductieklasse afgeleid uit de KLW dataset 2017, 2018 en 2019.

- Voor het melkproductietraject van 3000 tot $13000 \mathrm{~kg}$ melk per koe zijn de nieuwe schattingsformules:

$\mathrm{N}$-excretie, in kg per koe per jaar $=145,6+0,0079365 \times($ melk -8797$)+1,8 \times($ ureum $-22,5)$ $\mathrm{P}_{2} \mathrm{O}_{5}$-excretie, in $\mathrm{kg}$ per koe per jaar $=40,6+0,0015533 \times(\mathrm{melk}-8797)$. 


\section{$4 \quad$ Impact nieuwe schattingsformules}

\subsection{Nieuwe schattingsformules versus KLW data}

Met de nieuwe schattingsformules uit hoofdstuk 3 kunnen $\mathrm{N}$ - en $\mathrm{P}_{2} \mathrm{O}_{5}$-excreties worden berekend als functie van melkproductie per koe. De nieuwe schattingsformules voor de bruto excretie zijn:

$\mathrm{N}$-excretie, in kg per koe per jaar $=145,6+0,0079365 \times($ melk -8797$)+1,8 \times($ ureum $-22,5)$ $\mathrm{P}_{2} \mathrm{O}_{5}$-excretie, in kg per koe per jaar $=40,6+0,0015533 \times($ melk -8797$)$

Figuur 4.1 geeft de verschillen weer tussen de resultaten van de nieuwe schattingsformules en de resultaten afgeleid van de $\mathrm{KLW}$-data voor de bruto $\mathrm{N}$ - en $\mathrm{P}_{2} \mathrm{O}_{5}$-excreties. In Figuur $4.1 \mathrm{a}$ is het verschil weergegeven in $\mathrm{kg}$ en in Figuur 4.1b is het verschil weergegeven in \%. De waarde 0 op de y-as geeft aan dat de excretie volgens de schattingsformules gelijk is aan de excretie afgeleid van de KLW-data. Waarden boven nul in de figuur geven aan dat de excreties volgens de schattingsformules lager zijn dan de excreties afgeleid uit de KLW-data. Omgekeerd, waarden lager dan nul geven aan dat de excreties volgens de schattingsformules hoger zijn dan de excreties afgeleid uit de KLW-data.

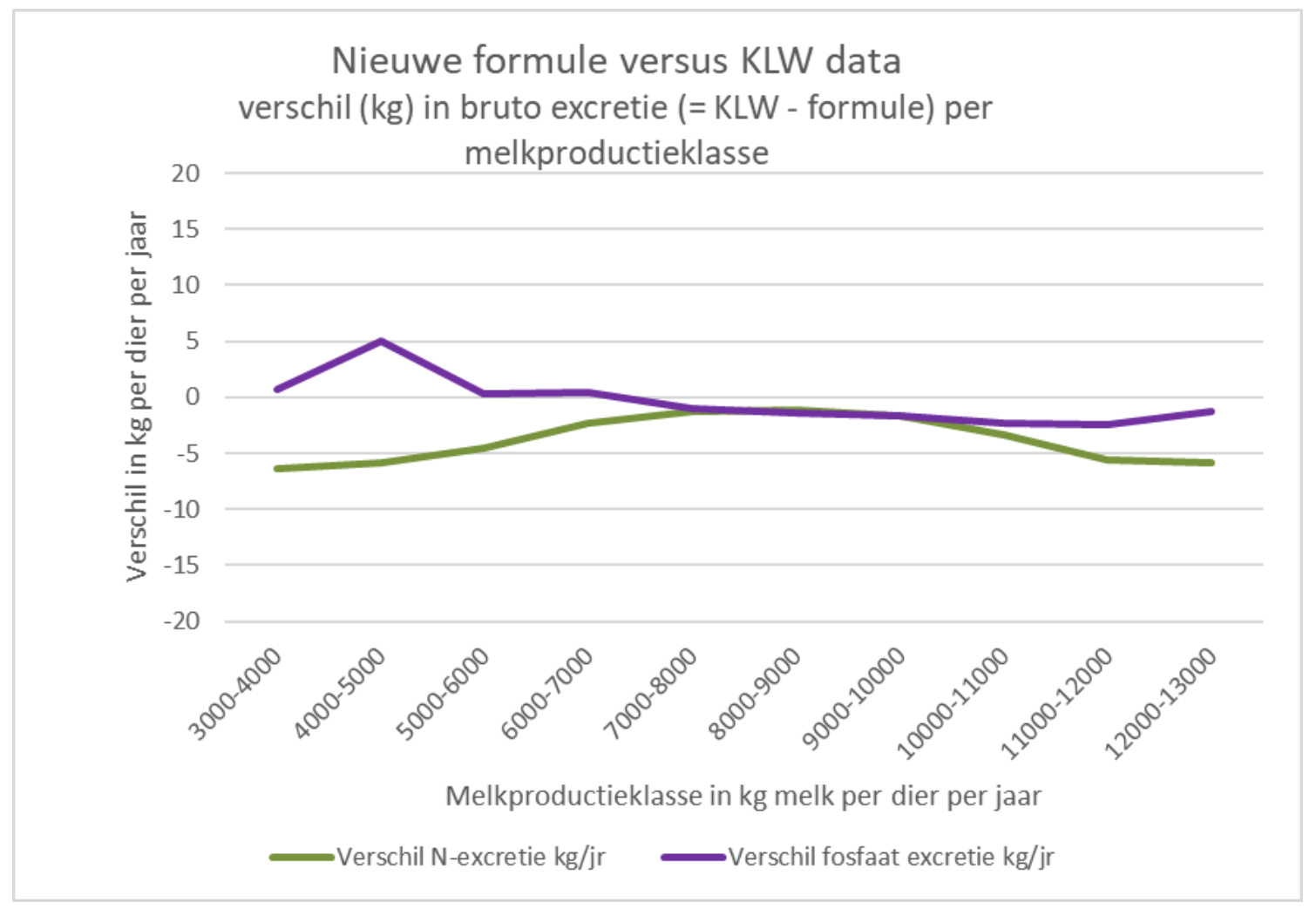

Figuur 4.1 a Verschillen (in kg per koe per jaar) tussen resultaten verkregen met de nieuwe schattingsformules en die van de KLW dataset uit 2017, 2018 en 2019, voor N- en $\mathrm{P}_{2} \mathrm{O}_{5}-$ excreties in $\mathrm{kg}$ per koe per jaar, als functie van het melkproductieniveau. 


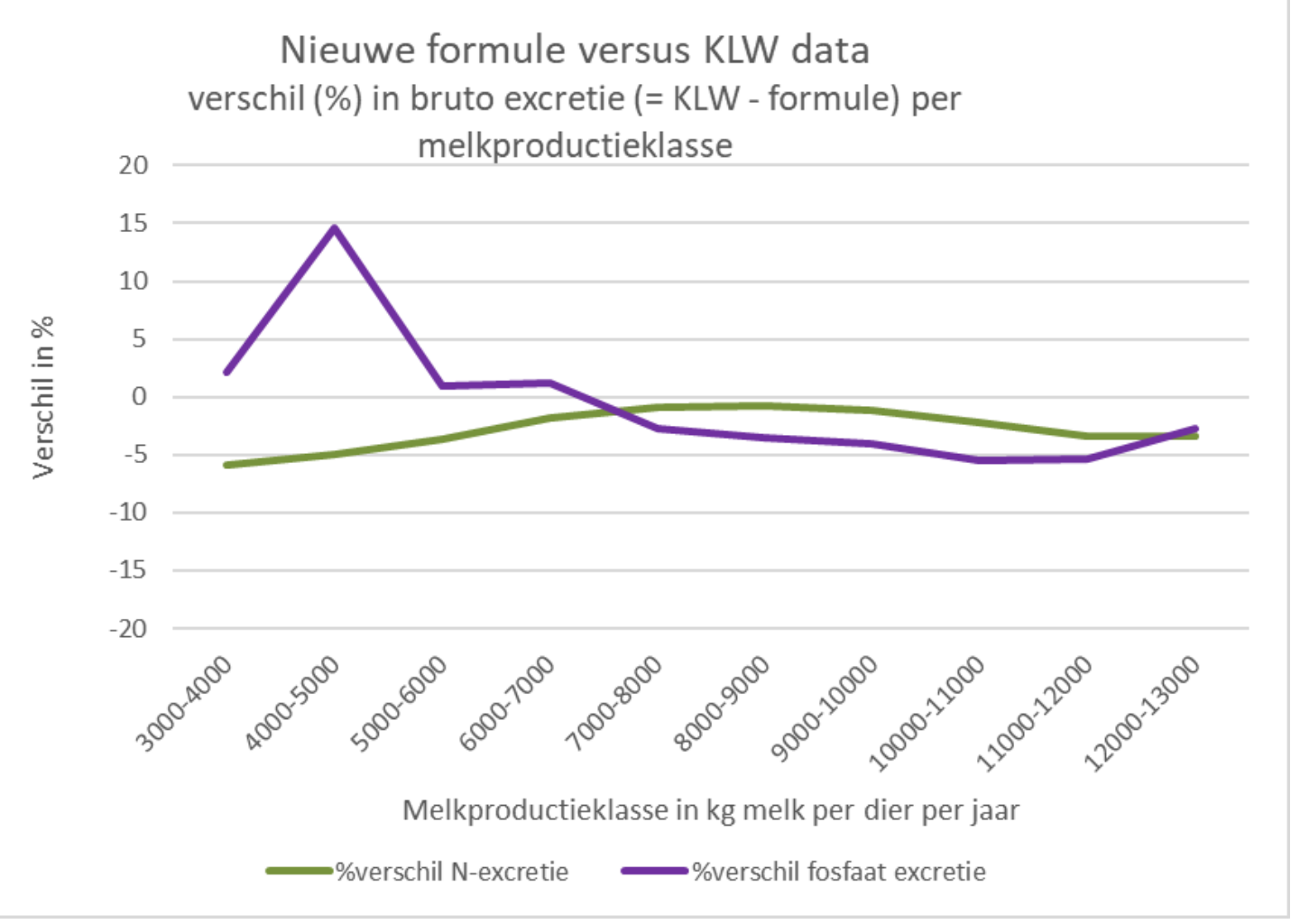

Figuur 4.1b Verschillen (in procenten) tussen resultaten verkregen met de nieuwe schattingsformules en die van de KLW dataset uit 2017, 2018 en 2019, voor $\mathrm{N}$ - en $\mathrm{P}_{2} \mathrm{O}_{5}$-excreties in $\mathrm{kg}$ per koe per jaar, als functie van het melkproductieniveau.

De excreties afgeleid met de nieuwe schattingsformules passen beduidend beter bij de waarnemingen in de KLW dataset dan de huidige formules (vergelijk figuur 4.1a met figuren 2.5 en 3.1). De nieuwe formules geven relatief kleine verschillen met de excreties afgeleid uit de KLW data voor de jaren 2017-2019 (de praktijk van de Nederlandse melkveehouderij). Ook zijn deze verschillen nagenoeg onafhankelijk van het melkproductieniveau. Uitgedrukt in procenten (Figuur 4.1b) blijven de verschillen over de gehele range van 3000-13000 kg melk binnen de 5\% (de waarneming voor fosfaat bij de melkproductieklasse $4000-5000 \mathrm{~kg}$ is atypisch en is hierbij buiten beschouwing gelaten). 


\subsection{Huidige forfaits versus voorgestelde nieuwe forfaits}

\subsubsection{Algemeen}

De nieuwe schattingsformules zijn gebruikt om een voorstel te maken voor een update van de forfaitaire excretietabellen (Bijlage 4 voor drijfmest en Bijlage 5 voor vaste mest). De impact van de nieuwe excretieforfaits kan voor melkveebedrijven groot zijn. Om een beeld te krijgen van deze impact zijn in Figuur 4.2 (voor $\mathrm{N}$ ) en Figuur 4.3 (voor $\mathrm{P}_{2} \mathrm{O}_{5}$ ) de excretieforfaits volgens de nieuwe schattingsformules en volgens de huidige forfaits (conform bijlage $D$ van de Uitvoeringsregeling Meststoffenwet) weergegeven. Dit is gedaan voor melkproducties oplopend van 1000 tot $15000 \mathrm{~kg}$ melk per dier per jaar en bij een melkureumgehalte van $22,5 \mathrm{mg} / 100 \mathrm{~g}$ melk.

\subsubsection{N-excretie}

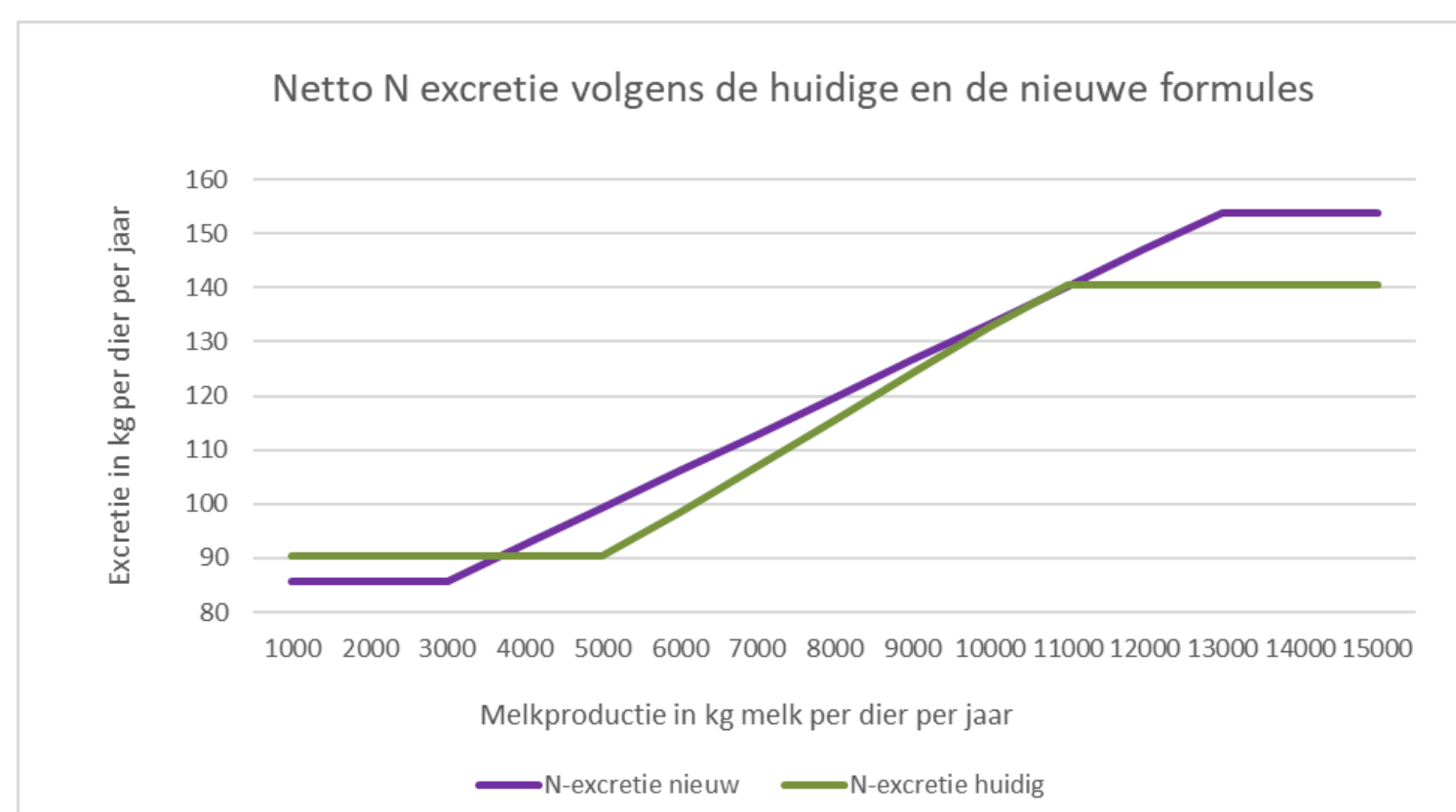

Figuur 4.2 Netto N-excreties (in kg per koe per jaar) als functie van het melkproductieniveau: resultaten van de huidige forfaits (excretie huidig) en met de voorgestelde nieuwe schattingsformules (excretie nieuw). Merk op dat de huidige excretieforfaits en de voorgestelde nieuwe forfaits niet over hetzelfde melkproductietraject zijn gedifferentieerd.

Voor de forfaitaire N-excretie (Figuur 4.2) blijkt dat de voorgestelde nieuwe forfaits verschillen van de huidige forfaits. Voor melkproducties beneden de $3700 \mathrm{~kg}$ per koe per jaar zijn de nieuwe forfaits ca. $5,5 \%$ lager, rond $3700 \mathrm{~kg}$ melk per koe per jaar zijn de nieuwe forfaits gelijk aan de huidige, en vanaf $3700 \mathrm{~kg}$ melk per koe per jaar zijn de nieuwe forfaits hoger waarbij het verschil afhankelijk is van het melkproductieniveau. Uitzondering daarop zijn melkproducties tussen de 9000-11500 waarvoor de nieuwe en huidige forfaits niet noemenswaardig verschillen (minder dan $2 \%$ ).

De voorgestelde nieuwe forfaits zijn hoger dan de huidige forfaits bij melkproducties tussen $3700 \mathrm{~kg}$ en $9000 \mathrm{~kg}$ per koe per jaar. Deze hogere waarden zijn het gevolg van veranderingen in het gemiddelde $\mathrm{N}$-gehalte in rantsoenen van melkvee (Tabel 4.1). Het gemiddelde $\mathrm{N}$-gehalte van het rantsoen is met $1,6 \mathrm{~g} / \mathrm{kg}$ DS toegenomen waardoor bij een melkproductie van $8048 \mathrm{~kg}$ per dier per jaar (gemiddelde melkproductieniveau van de huidige forfaits) de $\mathrm{N}$-opname met $13,0 \mathrm{~kg}$ is toegenomen. Aangezien de vastlegging van $\mathrm{N}$ per melkproductieklasse nagenoeg gelijk is gebleven (vrij constant melkeiwit-gehalte) betekent een toename in de $\mathrm{N}$ opname een bijna even grote toename van de bruto $\mathrm{N}$-excretie.

De toename in de forfaitaire $\mathrm{N}$-excretie is echter minder groot dan op basis van de veranderingen in $\mathrm{N}$-opname zou worden verwacht, omdat de stikstofcorrectiefactoren voor gasvormige verliezen in 
dezelfde periode zijn aangepast van gemiddeld 8,5\% naar gemiddeld $14 \%$. Hierdoor komt de toename in het $\mathrm{N}$-excretieforfait uit op een verschil van 4,2 kg N per koe per jaar bij $8048 \mathrm{~kg}$ melk.

Tabel 4.1 Gemiddelde melkproducties per koe en de gemiddelde N- en P-gehalten van het Nederlandse melkveerantsoen over de perioden van de huidige forfaits (2010-2012) en de nieuw voorgestelde forfaits (2017-2019). Bron: WUM.

\begin{tabular}{|c|c|c|c|c|c|c|c|c|}
\hline & \multicolumn{6}{|c|}{ Jaar } & \multicolumn{2}{|c|}{ Gemiddelden } \\
\hline & 2010 & 2011 & 2012 & 2017 & 2018 & 2019 & 2010-2012 & 2017-2019 \\
\hline $\mathrm{N}$-gehalte rantsoen (g/kg DS) & 25,66 & 25,25 & 24,31 & 26,75 & 26,83 & 26,55 & 25,07 & 26,71 \\
\hline Melkproductie (kg/jaar) & 8075 & 8063 & 8006 & 8674 & 8869 & 8869 & 8048 & 8797 \\
\hline
\end{tabular}

\subsection{3 $\quad \mathrm{P}_{2} \mathrm{O}_{5}$-excretie}

De voorgestelde nieuwe forfaits voor fosfaat verschillen van de huidige forfaits voor fosfaat voor vrijwel alle melkproductieniveau's (Figuur 4.3). Voor melkproducties van $>7100 \mathrm{~kg}$ per koe zijn de nieuwe forfaits lager dan de huidige forfaits. Voor een melkproducties van $<3500 \mathrm{~kg}$ melk per dier per jaar is het verschil tussen de nieuwe en huidige forfaits relatief gering $\left(0,8 \mathrm{~kg} \mathrm{P}_{2} \mathrm{O}_{5}\right.$ of $\left.2 \%\right)$. Voor melkproducties tussen de 3500 en $7100 \mathrm{~kg}$ per dier per jaar zijn de nieuwe forfaits hoger dan de huidige forfaits, tot maximaal 2,2 kg (7\%) $\mathrm{P}_{2} \mathrm{O}_{5}$ bij $5000 \mathrm{~kg}$ melk per dier per jaar.

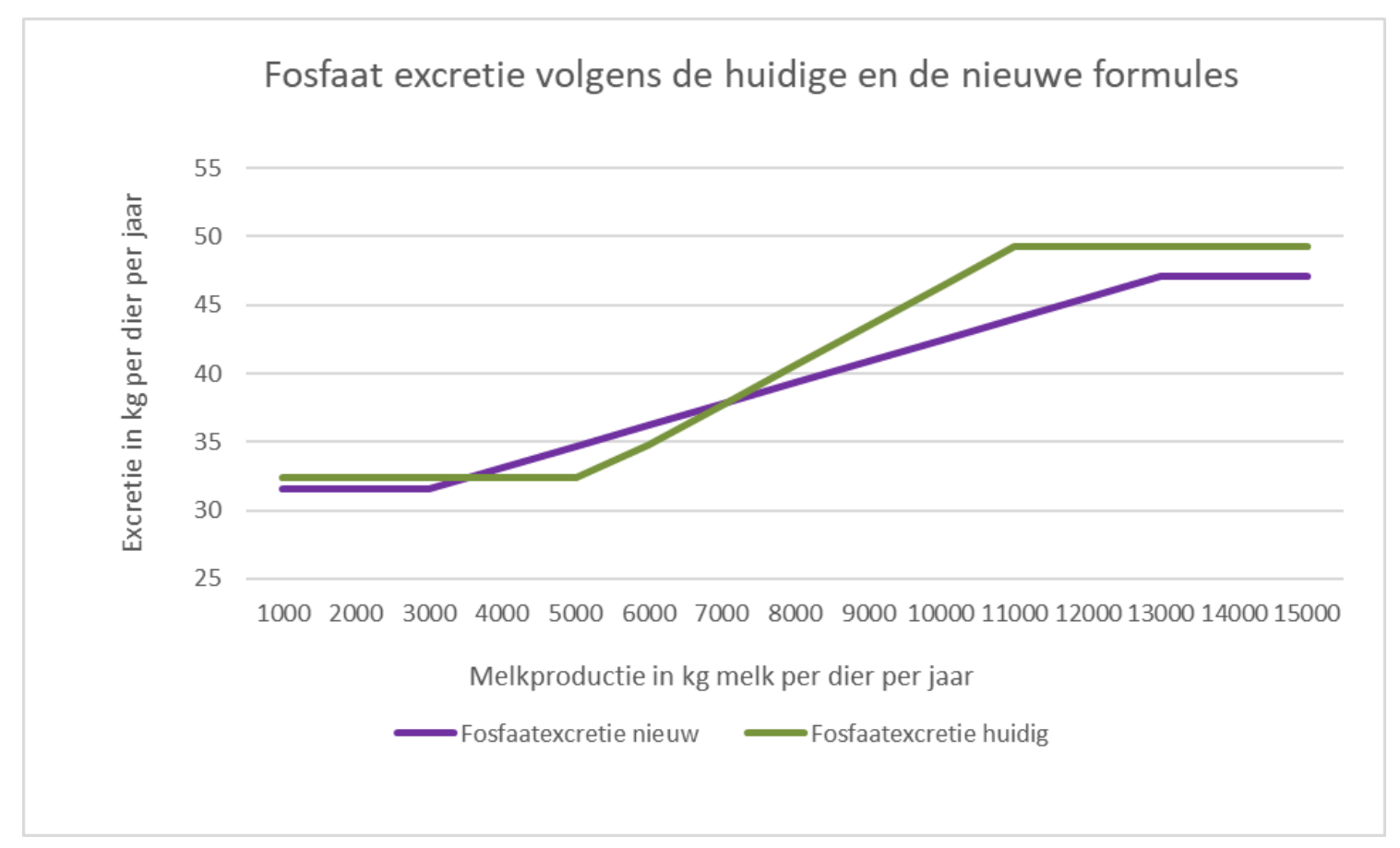

Figuur 4.3 $\mathrm{P}_{2} \mathrm{O}_{5}$-excreties (in $\mathrm{kg}$ per koe per jaar) als functie van het melkproductieniveau: resultaten van de huidige forfaits (excretie huidig) en met de voorgestelde nieuwe schattingsformules (excretie nieuw). Merk op dat de huidige excretieforfaits en de voorgestelde nieuwe forfaits niet over hetzelfde melkproductietraject zijn gedifferentieerd.

De verschillen tussen de huidige fosfaatexcretieforfaits en de voorgestelde nieuwe fosfaatexcretieforfaits zijn voor een groot deel toe te schrijven aan de aanpassing van de richtingscoëfficiënt van de schattingsformules, vooral ook door ontwikkelingen in het gemiddelde Pgehalte in rantsoenen van melkvee (Tabel 4.1). Het gemiddelde P-gehalte is met $0,1 \mathrm{~g} / \mathrm{kg} D S$ afgenomen waardoor bij een gelijke melkproductie van $8048 \mathrm{~kg}$ per dier per jaar (gemiddelde melkproductieniveau van de huidige forfaits) de P-opname met 0,7 kg is afgenomen. Bij gelijke Pvastlegging zou dat de fosfaatexcretie met $1,6 \mathrm{~kg}$ per dier verlagen. 


\subsection{Conclusies}

- De voorgestelde nieuwe $\mathrm{N}$ - en $\mathrm{P}_{2} \mathrm{O}_{5}$-excretieforfaits houden rekening met verschillen in de rantsoenen van melkvee die gerelateerd zijn aan de melkproductie per koe.

- De verschillen tussen de voorgestelde nieuwe $\mathrm{N}$ - en $\mathrm{P}_{2} \mathrm{O}_{5}$-excretieforfaits en de excreties zoals afgeleid uit de dataset van de KringloopWijzer over 2017, 2018 en 2019 zijn relatief klein en onafhankelijk van het melkproductieniveau.

- De voorgestelde nieuwe $\mathrm{N}$ - en $\mathrm{P}_{2} \mathrm{O}_{5}$-excretieforfaits wijken af van de huidige excretieforfaits. De verschillen zijn afhankelijk van het melkproductieniveau:

- Voor melkproducties lager dan ca $3500 \mathrm{~kg}$ per dier per jaar: De forfaitaire excretie neemt af; voor $\mathrm{N}$ met ongeveer $4,8 \mathrm{~kg}(5,3 \%)$ en voor $\mathrm{P}_{2} \mathrm{O}_{5}$ met ongeveer $0,8 \mathrm{~kg}(2,5 \%)$.

- Voor melkproducties van ca 3500 - $7100 \mathrm{~kg}$ per dier per jaar: De forfaitaire excretie neemt toe en de toename is afhankelijk van het melkproductieniveau; voor $\mathrm{N}$ maximaal met ongeveer $8,8 \mathrm{~kg}(9,8 \%)$ en voor $\mathrm{P}_{2} \mathrm{O}_{5}$ maximaal met ongeveer $2,3 \mathrm{~kg}(7,1 \%)$.

- Voor melkproducties hoger dan ca $7100 \mathrm{~kg}$ per dier per jaar:

- Voor $\mathrm{N}$ : de forfaitaire excretie neemt toe of blijft nagenoeg gelijk (van ca 9000-11500 kg melk per dier per jaar). De toename is afhankelijk van het melkproductieniveau en is maximaal $13,4 \mathrm{~kg}(9,5 \%)$ vanaf $13000 \mathrm{~kg}$ melk per dier per jaar.

- Voor $\mathrm{P}_{2} \mathrm{O}_{5}$ : de forfaitaire excretie neemt af. De afname is afhankelijk van het melkproductieniveau en is maximaal $5,3 \mathrm{~kg}(10,7 \%)$ bij $11000 \mathrm{~kg}$ melk per dier per jaar. Vanaf $11000 \mathrm{~kg}$ melk wordt de afname minder en vanaf $13000 \mathrm{~kg}$ melk per dier per jaar het nieuwe forfait constant $2,2 \mathrm{~kg}(4,4 \%)$ lager dan het huidige forfait. 


\section{Voorgestelde forfaits en productieruimte}

\section{$5.1 \quad$ Inleiding}

Het aanpassen van de excretieforfaits kan invloed hebben op de grootte van de benodigde mestafvoer van melkveebedrijven, en op de productieruimte van afzonderlijke melkveebedrijven en/of van de melkveesector als geheel indien de forfaits in het fosfaatrechtenstelsel ook zouden worden geactualiseerd. Dit hoofdstuk beschrijft een analyse van het effect van de voorgestelde nieuwe excretieforfaits op de productieruimte binnen het fosfaatrechtenstelsel voor stikstof en fosfaat van melkveebedrijven en van de sector als geheel.

\subsection{Uitgangspunten}

- $\quad$ De bedrijven benutten de beschikbare fosfaatrechten maximaal, zowel bij de huidige forfaits als in de situatie met de voorgestelde forfaits;

- De forfaitaire fosfaatproductie in 2020 met de huidige (nu geldende) forfaits is beschouwd als representatief voor de beschikbare en benutte fosfaatrechten. De forfaitaire fosfaatproductie is berekend met de huidige forfaits voor:

- melkkoeien (categorie 100);

- vrouwelijk en mannelijk jongvee in de melkveehouderij jonger dan 1 jaar (categorie 101);

- vrouwelijk jongvee in de melkveehouderij van 1 jaar en ouder (categorie 102);

- vrouwelijk jongvee in de vleesveehouderij (categorie 101 en 102);

- De fosfaatproductie in 2020 is eveneens berekend met de voorgestelde, gewijzigde forfaits voor melkkoeien (categorie 100) en de ongewijzigde, huidige forfaits voor jongvee;

- $\quad$ Er is bij de berekening van de fosfaatproductie uitgegaan van de landbouwtelling van 2020 met het aantal dieren op de peildatum;

- De melkproductie per bedrijf (bron RVO) is op bedrijfsniveau gekoppeld aan de landbouwtelling (aantal dieren). Als er geen koppeling mogelijk was tussen de gegevens over de melkproductie per bedrijf en de landbouwtelling, dan is voor die bedrijven uitgegaan van de forfaits in de klasse met de gemiddelde melkproductie per koe: $8625-8874 \mathrm{~kg}$, met als extra voorwaarde (arbitrair) dat er minimaal 10 melkkoeien op het bedrijf zijn.

Opmerking m.b.t. de voorgestelde forfaits:

De berekening van de voorgestelde forfaits is conform de gangbare methodiek (Bikker e.a., 2019) uitgevoerd en maakt gebruik van de relatie tussen de melkproductie en de excretie. Daarbij is die relatie, anders dan in voorgaande aanpassingen, vastgesteld op basis van de rantsoenen (per $1000 \mathrm{~kg}$ melk) in de Centrale Database van de KringloopWijzer (CD-KLW) over 2017, 2018 en 2019. Hierdoor sluiten de voorgestelde forfaits goed aan bij de praktijkexcreties, maar wijken ze met name voor fosfaat af van de huidige forfaits die zijn afgeleid toen het actief sturen op lage P-excreties via rantsoenaanpassingen nog niet in de brede praktijk werd toegepast.

\subsection{Gebruikte data}

De gebruikte data waren afkomstig van 2 bronnen:

1. Centrale Database KringloopWijzer (CD-KLW) 2019.

2. Landbouwtelling 2020 en melkleveringen 2020. 
Tabel 5.1 geeft een overzicht van het aantal bedrijven en het aantal melkkoeien van de gebruikte datasets (i.c. Landbouwtelling en CD-KLW).

Tabel 5.1 Aantal bedrijven en melkkoeien in de landbouwtelling van 2020 en in de CD-KLW van 2019.

\begin{tabular}{|c|c|c|c|c|}
\hline & $\begin{array}{c}\text { Bedrijven met } \\
\text { melkkoeien }\end{array}$ & $\begin{array}{r}\text { Waarvan met } \\
\text { bekende } \\
\text { melkproductie }\end{array}$ & $\begin{array}{r}\text { Waarvan met } \\
\text { onbekende } \\
\text { melkproductie } \\
\text { maar met } 10 \text { of } \\
\text { meer koeien }\end{array}$ & $\begin{array}{r}\text { Waarvan met } \\
\text { onbekende } \\
\text { melkproductie en } \\
\text { minder dan } 10 \\
\text { koeien }\end{array}$ \\
\hline \multicolumn{5}{|l|}{ Landbouwtelling 2020} \\
\hline Aantal bedrijven & 15.731 & 14.854 & 429 & 448 \\
\hline Aantal melkkoeien & 1.593 .071 & 1.544 .099 & 47.441 & 1.531 \\
\hline \multicolumn{5}{|l|}{ CD-KLW 2019} \\
\hline Aantal bedrijven & 14.836 & 14.836 & & \\
\hline Aantal melkkoeien & 1.523 .741 & 1.523 .741 & & \\
\hline
\end{tabular}

In de landbouwtelling van 2020 komen 15.731 bedrijven voor met melkkoeien, met in totaal 1.593.071 melkkoeien op de peildatum. Van 15.283 bedrijven is de melkproductie bekend (bron RVO). Voor 14.854 bedrijven met in totaal 1.544 .099 melkkoeien in de landbouwtelling van 2020 kon de melkproductie van het bedrijf worden gekoppeld aan het aantal melkkoeien, zodat een melkproductieklasse ( $\mathrm{kg}$ melk per koe) kon worden bepaald.

In de CD-KLW van 2019 komen 14.836 bedrijven voor met in totaal 1.523.741 melkkoeien. Van alle 14.836 bedrijven in de CD-KLW van 2019 is de melkproductie bekend.

De forfaitaire fosfaatproductie is berekend voor de huidige situatie (i.c. 2020 voor de landbouwtelling) met zowel de nu geldende forfaits als met de voorgestelde forfaits. Ook voor het aanwezige jongvee op bedrijven met melkvee in de landbouwtelling van 2020 zijn fosfaatrechten berekend, met inbegrip van het vrouwelijk jongvee in de categorieën 'jongvee voor de vleesproductie'. Het is immers niet bekend of dit jongvee al dan niet bestemd is om een kalf te krijgen. De berekening van de fosfaatrechten voor jongvee zijn ter informatie, aangezien de forfaitaire fosfaatproductie voor jongvee niet verandert.

In Tabel 5.2 zijn de resultaten van de forfaitaire fosfaatproductie per melkproductieklasse weergegeven. De voorgestelde netto forfaitaire stikstofexcretie en fosfaatexcretie zijn opgenomen in de bijlagen 3 en 4. Van 1.544.099 melkkoeien in de landbouwtelling kon de bijbehorende productieklasse worden bepaald. Voor 429 bedrijven met minimaal 10 melkkoeien per bedrijf (totaal 47.441 melkkoeien) is uitgegaan van de forfaits die horen bij de gemiddelde melkproductie in 2020 in de klasse 8625-8874 kg melk per koe. 
Tabel 5.2 Forfaitaire fosfaatproductie per melkproductieklasse en als totaal op basis van de landbouwtelling van 2020 berekend met de huidige en met de voorgestelde forfaits voor melkvee.

\begin{tabular}{|c|c|c|c|c|c|c|c|}
\hline Melkproductie & Bedrijven & Melkkoeien & $\begin{array}{l}\text { Ureum } \\
\text { (gem) }\end{array}$ & $\begin{array}{c}\text { Forfaitaire } \\
\text { productie } \\
\text { bij huidige } \\
\text { forfaits }\end{array}$ & $\begin{array}{l}\text { Forfaitaire } \\
\text { productie } \\
\text { bij voor- } \\
\text { gestelde } \\
\text { forfaits }\end{array}$ & $\begin{array}{r}\text { Versch } \\
\text { voorgestelc } \\
\text { huidige }\end{array}$ & $\begin{array}{l}\text { tussen } \\
\text { e forfaits en } \\
\text { orfaits }^{1} \text { ) }\end{array}$ \\
\hline Klasse & aantal & aantal & $(\mathrm{mg} / 100 \mathrm{~g})$ & $\mathrm{kg} \mathrm{P}_{2} \mathrm{O}_{5} / \mathrm{jr}$ & $\mathrm{kg} \mathrm{P}_{2} \mathrm{O}_{5} / \mathrm{jr}$ & $\mathrm{kg} \mathrm{P}_{2} \mathrm{O}_{5} / \mathrm{jr}$ & $\begin{array}{c}\mathrm{kg}_{2} \mathrm{O}_{5} \text { per } \\
\text { bedrijf/jr }\end{array}$ \\
\hline $0-2874$ & 149 & 12.911 & 22,2 & 521.414 & 511.086 & -10.329 & -69 \\
\hline $2875-3124$ & 20 & 1.743 & 22,7 & 71.894 & 70.499 & -1.394 & -70 \\
\hline $3125-3374$ & 38 & 2.415 & 22,3 & 98.843 & 97.877 & -966 & -25 \\
\hline $3375-3624$ & 40 & 2.985 & 22,8 & 121.101 & 121.101 & 0 & 0 \\
\hline $3625-3874$ & 40 & 2.015 & 22,3 & 85.894 & 86.700 & 806 & 20 \\
\hline $3875-4124$ & 55 & 3.434 & 22,5 & 143.394 & 145.798 & 2.404 & 44 \\
\hline $4125-4374$ & 49 & 3.053 & 23,4 & 127.578 & 130.936 & 3.358 & 69 \\
\hline $4375-4624$ & 68 & 4.143 & 23,7 & 174.921 & 181.136 & 6.215 & 91 \\
\hline $4625-4874$ & 85 & 5.004 & 23,7 & 209.264 & 218.771 & 9.508 & 112 \\
\hline $4875-5124$ & 107 & 6.002 & 23,5 & 243.990 & 257.795 & 13.805 & 129 \\
\hline $5125-5374$ & 114 & 7.700 & 22,9 & 319.765 & 340.555 & 20.790 & 182 \\
\hline $5375-5624$ & 129 & 8.006 & 22,2 & 330.416 & 355.235 & 24.819 & 192 \\
\hline $5625-5874$ & 142 & 10.198 & 23,0 & 433.559 & 452.935 & 19.376 & 136 \\
\hline $5875-6124$ & 195 & 13.825 & 22,9 & 597.997 & 618.734 & 20.738 & 106 \\
\hline $6125-6374$ & 209 & 15.622 & 22,8 & 687.326 & 704.510 & 17.184 & 82 \\
\hline $6375-6624$ & 281 & 23.159 & 22,5 & 1.026 .807 & 1.045 .334 & 18.527 & 66 \\
\hline $6625-6874$ & 345 & 26.229 & 22,7 & 1.185 .008 & 1.198 .122 & 13.115 & 38 \\
\hline $6875-7124$ & 398 & 33.877 & 22,4 & 1.544 .651 & 1.548 .039 & 3.388 & 9 \\
\hline $7125-7374$ & 454 & 37.983 & 22,4 & 1.767 .024 & 1.759 .428 & -7.597 & -17 \\
\hline $7375-7624$ & 541 & 46.549 & 22,1 & 2.198 .038 & 2.174 .764 & -23.275 & -43 \\
\hline $7625-7874$ & 643 & 60.653 & 22,1 & 2.881 .701 & 2.833 .179 & -48.522 & -75 \\
\hline $7875-8124$ & 791 & 76.935 & 21,7 & 3.721 .802 & 3.629 .480 & -92.322 & -117 \\
\hline $8125-8374$ & 856 & 83.580 & 21,8 & 4.097 .468 & 3.972 .098 & -125.370 & -146 \\
\hline $8375-8624$ & 1.015 & 104.427 & 21,5 & 5.208 .058 & 5.009 .646 & -198.411 & -195 \\
\hline $8625-8874$ & 1.079 & 112.612 & 21,4 & 5.684 .794 & 5.437 .047 & -247.746 & -230 \\
\hline $8875-9124$ & 1.233 & 135.767 & 21,4 & 6.981 .991 & 6.628 .997 & -352.994 & -286 \\
\hline $9125-9374$ & 1.068 & 121.149 & 21,2 & 6.315 .387 & 5.964 .055 & -351.332 & -329 \\
\hline $9375-9624$ & 1.004 & 118.791 & 21,0 & 6.291 .578 & 5.911 .447 & -380.131 & -379 \\
\hline $9625-9874$ & 875 & 101.004 & 21,1 & 5.409 .008 & 5.055 .494 & -353.514 & -404 \\
\hline $9875-10124$ & 731 & 91.623 & 21,0 & 4.982 .783 & 4.625 .453 & -357.330 & -489 \\
\hline $10125-10374$ & 586 & 76.180 & 21,0 & 4.200 .624 & 3.880 .668 & -319.956 & -546 \\
\hline $10375-10624$ & 426 & 52.630 & 21,0 & 2.944 .653 & 2.702 .555 & -242.098 & -568 \\
\hline $10625-10874$ & 294 & 38.207 & 21,0 & 2.190 .890 & 1.973 .110 & -217.780 & -741 \\
\hline $10875-11124$ & 205 & 26.142 & 20,9 & 1.499 .002 & 1.360 .450 & -138.553 & -676 \\
\hline $11125-11374$ & 192 & 23.057 & 20,7 & 1.324 .860 & 1.211 .881 & -112.979 & -588 \\
\hline $11375-11624$ & 103 & 14.882 & 20,9 & 857.917 & 790.948 & -66.969 & -650 \\
\hline $11625-11874$ & 76 & 10.226 & 20,5 & 594.922 & 552.996 & -41.927 & -552 \\
\hline $11875-12124$ & 57 & 8.165 & 20,9 & 466.542 & 436.331 & -30.211 & -530 \\
\hline $12125-12374$ & 42 & 6.329 & 20,7 & 359.161 & 338.276 & -20.886 & -497 \\
\hline $12375-12624$ & 32 & 4.169 & 20,8 & 243.748 & 231.658 & -12.090 & -378 \\
\hline $12625-12874$ & 19 & 2.556 & 21,2 & 148.514 & 141.868 & -6.646 & -350 \\
\hline $12875-13124$ & 20 & 1.982 & 20,8 & 121.632 & 117.271 & -4.360 & -218 \\
\hline$>13124$ & 48 & 6.180 & 21,0 & 369.654 & 356.058 & -13.596 & -283 \\
\hline Onbekend & 429 & 47.441 & . & 2.450 .239 & 2.345 .868 & -104.370 & -243 \\
\hline Totaal & 15.283 & 1.591 .540 & 21,6 & 81.235 .810 & 77.526 .187 & -3.709 .623 & -243 \\
\hline
\end{tabular}

1) Een positief getal geeft aan dat de forfaitaire productie bij de voorgestelde forfaits hoger uitvalt en er dus meer fosfaatrechten nodig zijn. Een negatief getal geeft aan dat de forfaitaire productie bij de voorgestelde forfaits lager uitvalt en dat er dus ruimte is voor extra productie. 


\subsection{Resultaten en conclusies}

\subsubsection{Fosfaatexcretie}

In totaal waren er in 2020 81,2 miljoen fosfaatrechten nodig bij de huidige forfaitaire productie en onder de hiervoor genoemde uitgangspunten. Bij de voorgestelde forfaits zijn 77,5 miljoen fosfaatrechten nodig. Als ervan uitgegaan wordt dat de productie in 2020 gerelateerd is aan de productieruimte bij de uitgedeelde rechten, dan betekent dit bij de voorgestelde forfaits per saldo een extra productieruimte van 3,7 miljoen $\mathrm{kg}$ fosfaat.

De geregistreerde melkproductie per koe van het gemiddelde melkveebedrijf lag in 2020 in de klasse 8625-8874 kg melk. Het gemiddelde melkveebedrijf heeft dus bij de voorgestelde forfaits een extra fosfaatruimte van $230 \mathrm{~kg}$ fosfaat wat overeenkomt met de forfaitaire fosfaatproductie van afgerond 5 melkkoeien.

In Figuur 5.1 is het gemiddelde verschil in forfaitaire fosfaatproductie per bedrijf weergegeven tussen de productie bij de voorgestelde forfaits en de productie bij de huidige forfaits. Figuur 5.2 geeft het daarbij betrokken aantal bedrijven en het aantal melkkoeien.

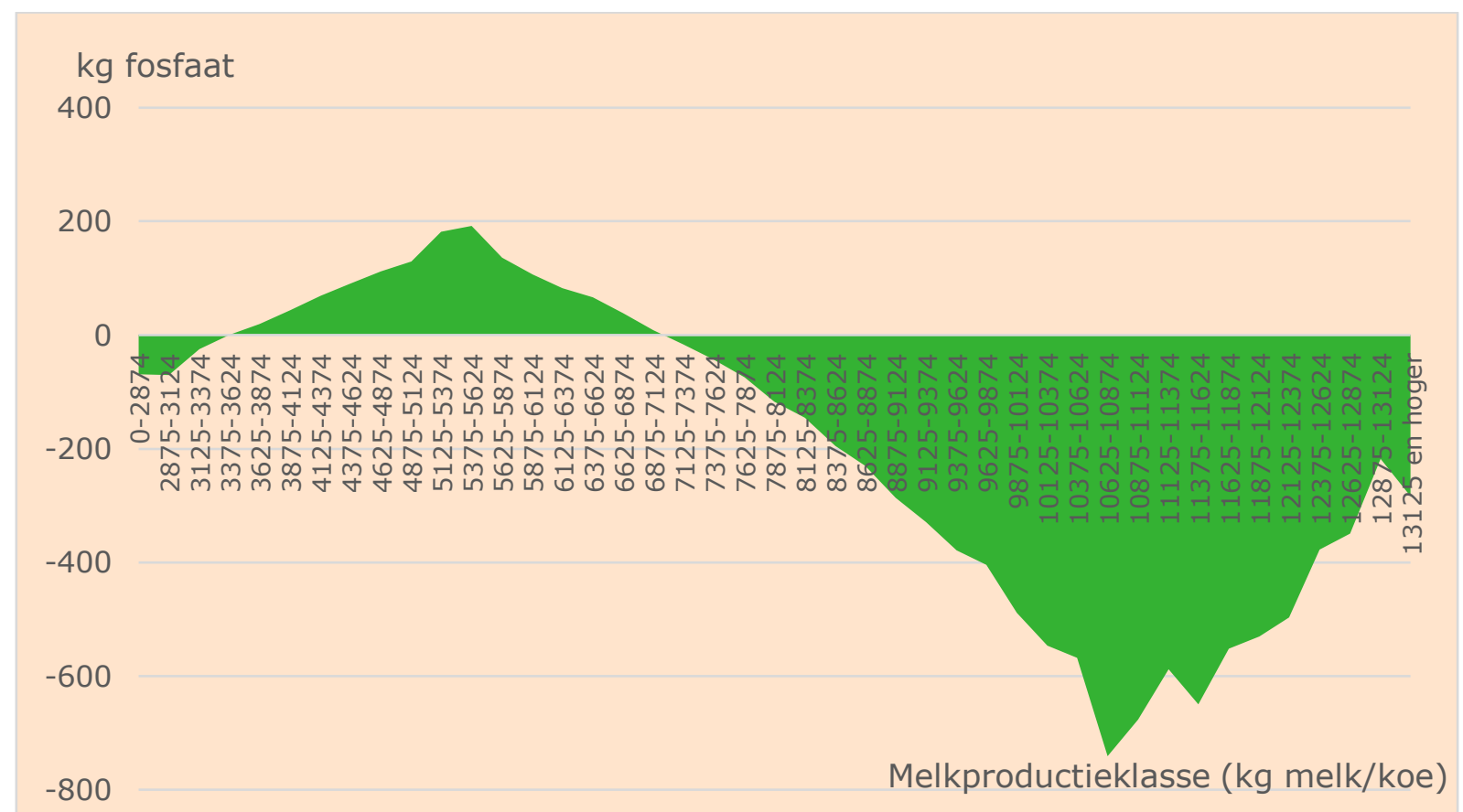

Figuur 5.1 Gemiddeld verschil in forfaitaire fosfaatproductie per bedrijf tussen de productie bij de voorgestelde forfaits en de fosfaatproductie bij de huidige forfaits. 


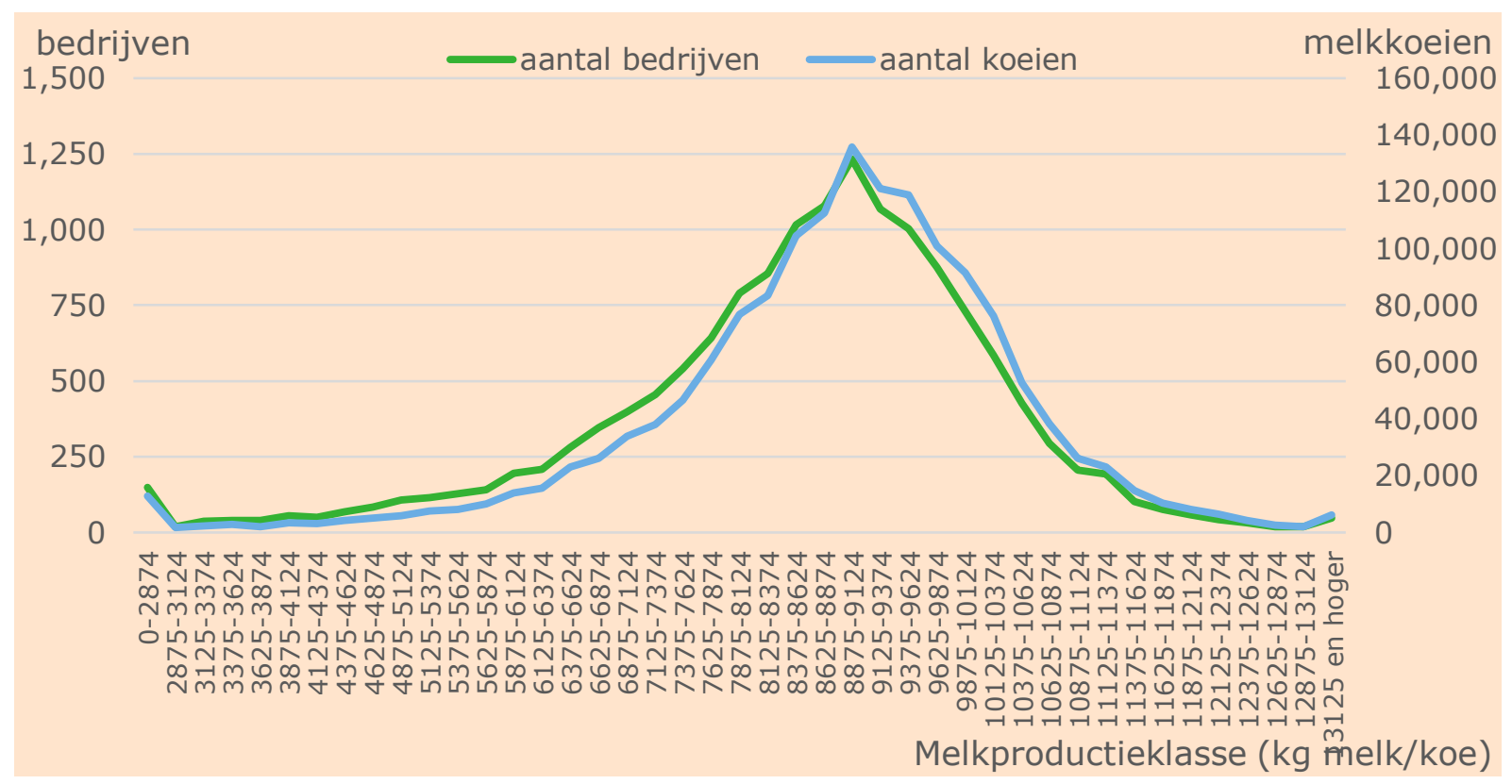

Figuur 5.2 Aantal bedrijven en aantal melkkoeien per melkproductieklasse

In Tabel 5.3 is een samenvatting gegeven van de resultaten waarbij de bedrijven zijn verdeeld in bedrijven met overproductie en bedrijven met productieruimte voor fosfaat bij de voorgestelde forfaits. Bedrijven waarvan de melkproductieklasse niet kon worden vastgesteld zijn buiten beschouwing gelaten.

Tabel 5.3 Bedrijven in de landbouwtelling 20201) met fosfaatoverproductie en bedrijven met fosfaatruimte bij toepassing van de voorgestelde forfaits.

\begin{tabular}{|c|c|c|c|}
\hline & aantal bedrijven & $\begin{array}{c}\text { aantal } \\
\text { melkkoeien }\end{array}$ & $\begin{array}{l}\text { kg fosfaat } \\
\text { productieruimte }\end{array}$ \\
\hline Bedrijven met overproductie t.o.v. huidige forfaits & 2.257 & 165.252 & -174.031 \\
\hline Bedrijven met productieruimte t.o.v. huidige forfaits & 12.597 & 1.378 .847 & 3.779 .283 \\
\hline Totaal & 14.854 & 1.544 .099 & 3.605 .253 \\
\hline
\end{tabular}

1) Uitsluitend bedrijven in de landbouwtelling waarvan de melkproductie bekend is.

Er zijn 2.257 bedrijven die bij de voorgestelde forfaits meer fosfaat produceren dan bij de huidige forfaits. Deze bedrijven hebben globaal 165.000 koeien en een gezamenlijke 'overproductie' van 0,174 miljoen $\mathrm{kg}$ fosfaat. Daarnaast zijn er 12.597 bedrijven die bij de voorgestelde forfaits minder fosfaat produceren dan bij de huidige forfaits. Deze bedrijven hebben globaal 1.379.000 koeien en een gezamenlijke ruimte van 3,779 miljoen $\mathrm{kg}$ fosfaat.

\subsubsection{Stikstofexcretie}

Als ervan uitgegaan wordt dat de extra productieruimte voor fosfaat daadwerkelijk wordt opgevuld, dan kan de toename van de bruto $\mathrm{N}$-excretie berekend worden door de N/ $\mathrm{P}_{2} \mathrm{O}_{5}$-verhouding ${ }^{7}(=3,89)$ van de excretie te vermenigvuldigen met de extra productieruimte voor fosfaat $(=3,605$, tabel 5.3$)$ :

Toename bruto $\mathrm{N}$-excretie $=3,89 \times 3,605=14,0$ miljoen $\mathrm{kg}$ stikstof

Een andere mogelijkheid is dat de bedrijven met een fosfaatoverschot worden ontzien. In dat geval is er een extra productieruimte die overeenkomt met 3,89 x 3,779=14,7 miljoen kg stikstof. Dit geeft een bandbreedte in de mogelijke toename van 14,0 - 14,7 miljoen kg stikstof bij toepassing van de voorgestelde forfaits. Cijfers van 2020 laten zien dat de stikstofexcretie van de melkveehouderij in 2020 gelijk was aan het productieplafond. ${ }^{8}$ Als de voorgestelde forfaits leiden tot een toename van de fosfaatproductie zal het lastig worden om overschrijding van het stikstofplafond te voorkomen.

\footnotetext{
7 De verhouding tussen de stikstof- en fosfaatexcretie van melkkoeien plus bijbehorend jongvee in 2019 (CBS, 2020).

${ }^{8}$ Hierbij is rekening gehouden met de zogeheten stikstofcorrectie waarbij de samenstelling van ruwvoer wordt gemiddeld over de afgelopen vijf jaar met weglating van de hoogste en laagste waarde.
} 


\subsubsection{Gevolgen op bedrijfsniveau}

Een melkveehouder kan op twee manieren reageren op de voorgestelde forfaits, namelijk zijn bedrijfsvoering aanpassen (= minder/meer dieren houden) of fosfaatrechten verwerven/vervreemden. In Tabel 5.4 is een indicatie weergegeven van het effect uitgedrukt in euro's van het gemiddelde fosfaatoverschot respectievelijk de fosfaatruimte die ontstaat bij toepassing van de voorgestelde forfaits. In Tabel 5.5 staat het effect uitgedrukt in aantallen melkkoeien. Hierbij is ervan uitgegaan dat het aandeel jongvee ten opzichte van de melkkoeien niet toe- of afneemt, met andere woorden als er koeien bijkomen of weggaan, dan neemt ook het aantal jongvee naar rato toe of af. 
Tabel 5.5 Gemiddeld aantal melkkoeien per bedrijf, gemiddeld aantal kalveren en pinken per koe en het effect op het aantal melkkoeien bij invoering van de voorgestelde forfaits.

\begin{tabular}{|c|c|c|c|c|c|c|c|}
\hline & Bedrijven & $\begin{array}{c}\text { Aantal } \\
\text { kalveren } \\
\text { per koe }\end{array}$ & $\begin{array}{c}\text { Aantal } \\
\text { pinken per } \\
\text { koe }\end{array}$ & \multicolumn{3}{|c|}{ Aantal melkkoeien } & $\begin{array}{c}\text { Toename/ } \\
\text { afname } \\
\text { aantal } \\
\text { koeien }\end{array}$ \\
\hline & aantal & gemiddeld & gemiddeld & gemiddeld & $\begin{array}{c}\text { 5- } \\
\text { percentiel }\end{array}$ & 95-percentiel & gemiddeld \\
\hline $0-2874$ & 149 & 0,28 & 0,32 & 87 & 16 & 273 & 2 \\
\hline $2875-3124$ & 20 & 0,28 & 0,33 & 87 & 22 & 239 & 2 \\
\hline $3125-3374$ & 38 & 0,26 & 0,28 & 64 & 21 & 156 & 1 \\
\hline $3375-3624$ & 40 & 0,23 & 0,26 & 75 & 22 & 215 & 0 \\
\hline $3625-3874$ & 40 & 0,28 & 0,34 & 50 & 15 & 106 & 0 \\
\hline $3875-4124$ & 55 & 0,36 & 0,35 & 62 & 17 & 139 & -1 \\
\hline $4125-4374$ & 49 & 0,31 & 0,33 & 62 & 20 & 116 & -2 \\
\hline $4375-4624$ & 68 & 0,25 & 0,35 & 61 & 14 & 134 & -2 \\
\hline $4625-4874$ & 85 & 0,31 & 0,30 & 59 & 20 & 100 & -3 \\
\hline $4875-5124$ & 107 & 0,28 & 0,30 & 56 & 17 & 109 & -3 \\
\hline $5125-5374$ & 114 & 0,26 & 0,31 & 68 & 20 & 176 & -4 \\
\hline $5375-5624$ & 129 & 0,30 & 0,30 & 62 & 16 & 140 & -4 \\
\hline $5625-5874$ & 142 & 0,28 & 0,27 & 72 & 25 & 154 & -3 \\
\hline $5875-6124$ & 195 & 0,28 & 0,29 & 71 & 19 & 145 & -2 \\
\hline $6125-6374$ & 209 & 0,30 & 0,26 & 75 & 21 & 173 & -2 \\
\hline $6375-6624$ & 281 & 0,27 & 0,27 & 82 & 26 & 181 & -1 \\
\hline $6625-6874$ & 345 & 0,27 & 0,25 & 76 & 26 & 148 & -1 \\
\hline $6875-7124$ & 398 & 0,26 & 0,25 & 85 & 24 & 186 & 0 \\
\hline $7125-7374$ & 454 & 0,27 & 0,26 & 84 & 25 & 175 & 0 \\
\hline $7375-7624$ & 541 & 0,27 & 0,25 & 86 & 33 & 177 & 1 \\
\hline $7625-7874$ & 643 & 0,27 & 0,25 & 94 & 30 & 187 & 2 \\
\hline $7875-8124$ & 791 & 0,27 & 0,25 & 97 & 37 & 201 & 2 \\
\hline $8125-8374$ & 856 & 0,27 & 0,24 & 98 & 38 & 201 & 3 \\
\hline $8375-8624$ & 1015 & 0,28 & 0,25 & 103 & 39 & 209 & 4 \\
\hline $8625-8874$ & 1079 & 0,28 & 0,24 & 104 & 40 & 203 & 5 \\
\hline $8875-9124$ & 1233 & 0,28 & 0,24 & 110 & 41 & 226 & 6 \\
\hline $9125-9374$ & 1068 & 0,28 & 0,24 & 113 & 45 & 237 & 7 \\
\hline $9375-9624$ & 1004 & 0,29 & 0,25 & 118 & 50 & 237 & 8 \\
\hline $9625-9874$ & 875 & 0,29 & 0,25 & 115 & 47 & 224 & 8 \\
\hline $9875-10124$ & 731 & 0,29 & 0,25 & 125 & 52 & 253 & 10 \\
\hline $10125-10374$ & 586 & 0,29 & 0,25 & 130 & 50 & 281 & 11 \\
\hline $10375-10624$ & 426 & 0,28 & 0,26 & 124 & 47 & 273 & 11 \\
\hline $10625-10874$ & 294 & 0,29 & 0,26 & 130 & 55 & 249 & 14 \\
\hline $10875-11124$ & 205 & 0,29 & 0,27 & 128 & 48 & 273 & 13 \\
\hline $11125-11374$ & 192 & 0,30 & 0,26 & 120 & 51 & 251 & 11 \\
\hline $11375-11624$ & 103 & 0,30 & 0,26 & 144 & 52 & 319 & 12 \\
\hline $11625-11874$ & 76 & 0,29 & 0,29 & 135 & 49 & 283 & 10 \\
\hline $11875-12124$ & 57 & 0,29 & 0,26 & 143 & 45 & 286 & 10 \\
\hline $12125-12374$ & 42 & 0,26 & 0,26 & 151 & 57 & 274 & 9 \\
\hline $12375-12624$ & 32 & 0,28 & 0,36 & 130 & 41 & 254 & 7 \\
\hline $12625-12874$ & 19 & 0,37 & 0,32 & 135 & 36 & 407 & 6 \\
\hline $12875-13124$ & 20 & 0,33 & 0,51 & 99 & 31 & 193 & 4 \\
\hline 13125 en hoger & 48 & 0,34 & 0,64 & 129 & 39 & 281 & 5 \\
\hline
\end{tabular}


- De beschikbare KringloopWijzer-dataset met ruwe data voor 2017, 2018 en 2019 is geschikt om conclusies te trekken over de relaties tussen rantsoensamenstelling en $\mathrm{N}$ - en $\mathrm{P}_{2} \mathrm{O}_{5}$-excreties van melkvee als functie van de melkproductie per koe (traject van 3000 tot $13000 \mathrm{~kg}$ melk per koe per jaar).

- De KringloopWijzer-dataset bevat vrijwel alle Nederlandse melkveebedrijven; ca. 20 bedrijven produceerden in de periode 2017-2019 minder dan $3000 \mathrm{~kg}$ melk per koe en ca. 10 bedrijven produceerden meer dan $13000 \mathrm{~kg}$ melk per koe per jaar.

- Voor het traject van 3000-13000 kg melk per koe per jaar zijn duidelijke lineaire trends waargenomen in rantsoensamenstelling, de nutriëntendichtheid van het rantsoen, de N- en Popname en de $\mathrm{N}$ - en $\mathrm{P}$-excreties per koe per jaar. Er kan voor alle melkproductieklassen met hetzelfde lineaire verband gerekend worden bij het afleiden van de $\mathrm{N}$ - en $\mathrm{P}_{2} \mathrm{O}_{5}$-excreties per koe per jaar.

- Voor het traject van 3000-13000 kg melk per koe per jaar verschillen de $\mathrm{N}$ - en $\mathrm{P}_{2} \mathrm{O}_{5}$-excreties afgeleid op basis van de schattingsformules voor de huidige excretieforfaits (Bikker et al., 2019), van de excreties afgeleid op basis van de KLW-dataset. De grootte van de verschillen varieert met het melkproductieniveau per koe. Op basis van deze verschillen is geconcludeerd dat de huidige schattingsformules geactualiseerd moeten worden.

- $\quad \mathrm{Bij}$ het actualiseren van de schattingsformules voor $\mathrm{N}$ - en $\mathrm{P}_{2} \mathrm{O}_{5}$-excreties is de bestaande methodiek, zoals beschreven door Bikker e.a., 2019, gehandhaafd. Wel is er verfijnd door gebruik te maken van de rantsoensamenstelling per melkproductieklasse afgeleid uit de KringloopWijzer-dataset voer 2017, 2018 en 2019.

- $\quad$ De nieuwe schattingsformules zijn:

$\mathrm{N}$-excretie, in kg per koe per jaar $=145,6+0,0079365 \times($ melk -8797$)+1,8 \times($ ureum $-22,5)$ $\mathrm{P}_{2} \mathrm{O}_{5}$-excretie, in $\mathrm{kg}$ per koe per jaar $=40,6+0,0015533 \times$ (melk -8797$)$.

- De nieuwe schattingsformules voor de $\mathrm{N}$ - en $\mathrm{P}_{2} \mathrm{O}_{5}$-excreties van melkkoeien:

- houden rekening met verschillen in de rantsoenen van melkvee die gerelateerd zijn aan de melkproductie per koe. Daardoor zijn de verschillen tussen de voorgestelde forfaits en de excreties op basis van de KringloopWijzer-dataset nagenoeg onafhankelijk van het melkproductieniveau.

- berekenen excreties die maximaal $5 \%$ afwijken van de excreties op basis van de KringloopWijzer-dataset.

- berekenen excreties die gemiddelde goed overeenkomen met de gemiddelde excreties van de Nederlandse melkveestapel zoals bepaald wordt door CBS/WUM.

○ kunnen gebruikt worden om de huidige $\mathrm{N}$ - en $\mathrm{P}_{2} \mathrm{O}_{5}$-excretieforfaits te actualiseren. 
- De voorgestelde nieuwe $\mathrm{N}$ - en $\mathrm{P}_{2} \mathrm{O}_{5}$-excretieforfaits wijken af van de huidige excretieforfaits. De verschillen zijn afhankelijk van het melkproductieniveau:

- Melkproducties lager dan ca $3500 \mathrm{~kg}$ per dier per jaar:

De forfaitaire excretie neemt af; voor $\mathrm{N}$ met ongeveer $4,8 \mathrm{~kg}(5,3 \%)$ en voor $\mathrm{P}_{2} \mathrm{O}_{5}$ met ongeveer $0,8 \mathrm{~kg}(2,5 \%)$.

- Melkproducties van ca $3500-7100 \mathrm{~kg}$ per dier per jaar:

De forfaitaire excretie neemt toe en de toename is afhankelijk van het melkproductieniveau; voor $\mathrm{N}$ maximaal met ongeveer $8,8 \mathrm{~kg}(9,8 \%)$ en voor $\mathrm{P}_{2} \mathrm{O}_{5}$ maximaal met ongeveer $2,3 \mathrm{~kg}$ $(7,1 \%)$.

- Melkproducties hoger dan ca $7100 \mathrm{~kg}$ per dier per jaar:

- $\quad$ Voor $N$ : de forfaitaire excretie neemt toe van 7100 tot $9000 \mathrm{~kg}$ en vanaf $11500 \mathrm{~kg}$ melk. De toename is afhankelijk van het melkproductieniveau en is maximaal $13,4 \mathrm{~kg}$ $(9,5 \%)$ vanaf $13000 \mathrm{~kg}$ melk per dier per jaar.

Van ca 9000 tot $11500 \mathrm{~kg}$ melk per dier per jaar zijn de voorgestelde nieuwe forfaits vrijwel gelijk aan de huidige forfaits.

- Voor $\mathrm{P}_{2} \mathrm{O}_{5}$ : de forfaitaire excretie neemt af. De afname is afhankelijk van het melkproductieniveau en is maximaal 5,3 kg (10,7\%) bij $11000 \mathrm{~kg}$ melk per dier per jaar. Vanaf $11000 \mathrm{~kg}$ melk wordt de afname minder en vanaf $13000 \mathrm{~kg}$ melk per dier per jaar het nieuwe forfait constant $2,2 \mathrm{~kg}(4,4 \%)$ lager dan het huidige forfait.

- De voorgestelde nieuwe $\mathrm{P}_{2} \mathrm{O}_{5}$-excretieforfaits vergroten per saldo de productieruimte voor melk, omdat er binnen de fosfaatrechten ruimte ontstaat voor ca. 3,6 miljoen $\mathrm{kg}$ extra fosfaatproductie.

- De productieruimte neemt af voor bedrijven die tussen de ca 3500-7100 kg melk per dier produceren. Het betreft 2.257 bedrijven met een totale overschrijding van de fosfaatrechten ter grootte van $174.031 \mathrm{~kg}$ fosfaat.

- De productieruimte neemt toe voor bedrijven die minder of meer dan ca $3500-7100 \mathrm{~kg}$ melk per dier produceren. Het betreft 12.597 bedrijven met een totale onderschrijding van de fosfaatrechten ter grootte van $3.779 .283 \mathrm{~kg}$ fosfaat.

- Wanneer de extra productieruimte op basis van fosfaat daadwerkelijk wordt opgevuld neemt de $\mathrm{N}$-excretie toe met 14,0 tot 14,7 miljoen $\mathrm{kg} \mathrm{N}$ per jaar, waardoor het lastig wordt om overschrijding van het stikstofplafond te voorkomen. 


\section{Literatuur}

Bikker,P., L.B. Šebek, C. van Bruggen \& O. Oenema, 2019. Stikstof- en fosfaatexcretie van gangbaar en biologisch gehouden landbouwhuisdieren. Herziening excretieforfaits Meststoffenwet 2019.

CBS (2020). Dierlijke mest en mineralen 2019. Centraal Bureau voor de Statistiek. Den Haag.

CVB, 2016. Tabellenboek Veevoeding 2016: voedernormen Rundvee, Schapen, Geiten en voederwaarden voedermiddelen voor Herkauwers. CVB-reeks nr. 52, November 2016.

RVO (2021). Handreiking bedrijfsspecifieke excretie melkvee. Versie per 14 mei 2021. https://www.rvo.nl/sites/default/files/2021/05/210527-Handreiking-BEX-2021-v1.pdf 


\section{Bijlage 1 Trends in rantsoenen (1)}

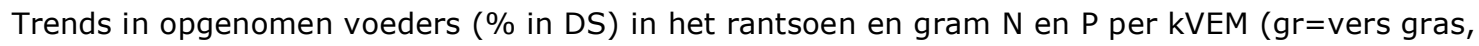
$\mathrm{gk}=$ graskuil, $\mathrm{sm}=$ snijmaiskuil, ov=overige producten, $\mathrm{kv}=\mathrm{krachtvoer}$ en $\mathrm{mp}=$ melkproducten).

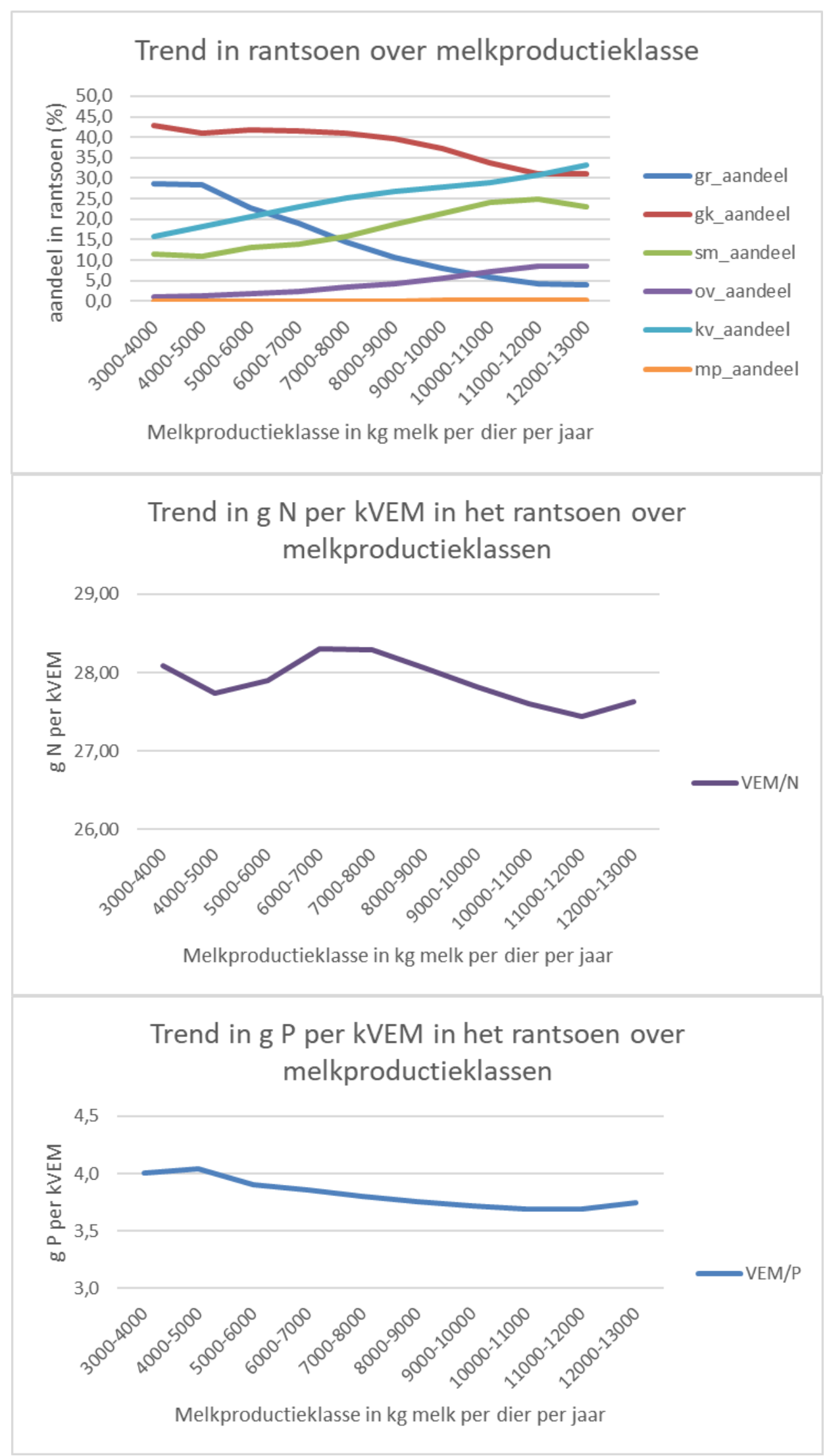




\section{Bijlage 2 Trends in rantsoenen (2)}

Trends in gehalten in de droge stof (DS): VEM (dimensie loos, per kg DS), $\mathrm{N}$ en $\mathrm{P}$ in gram per $\mathrm{kg}$ DS.
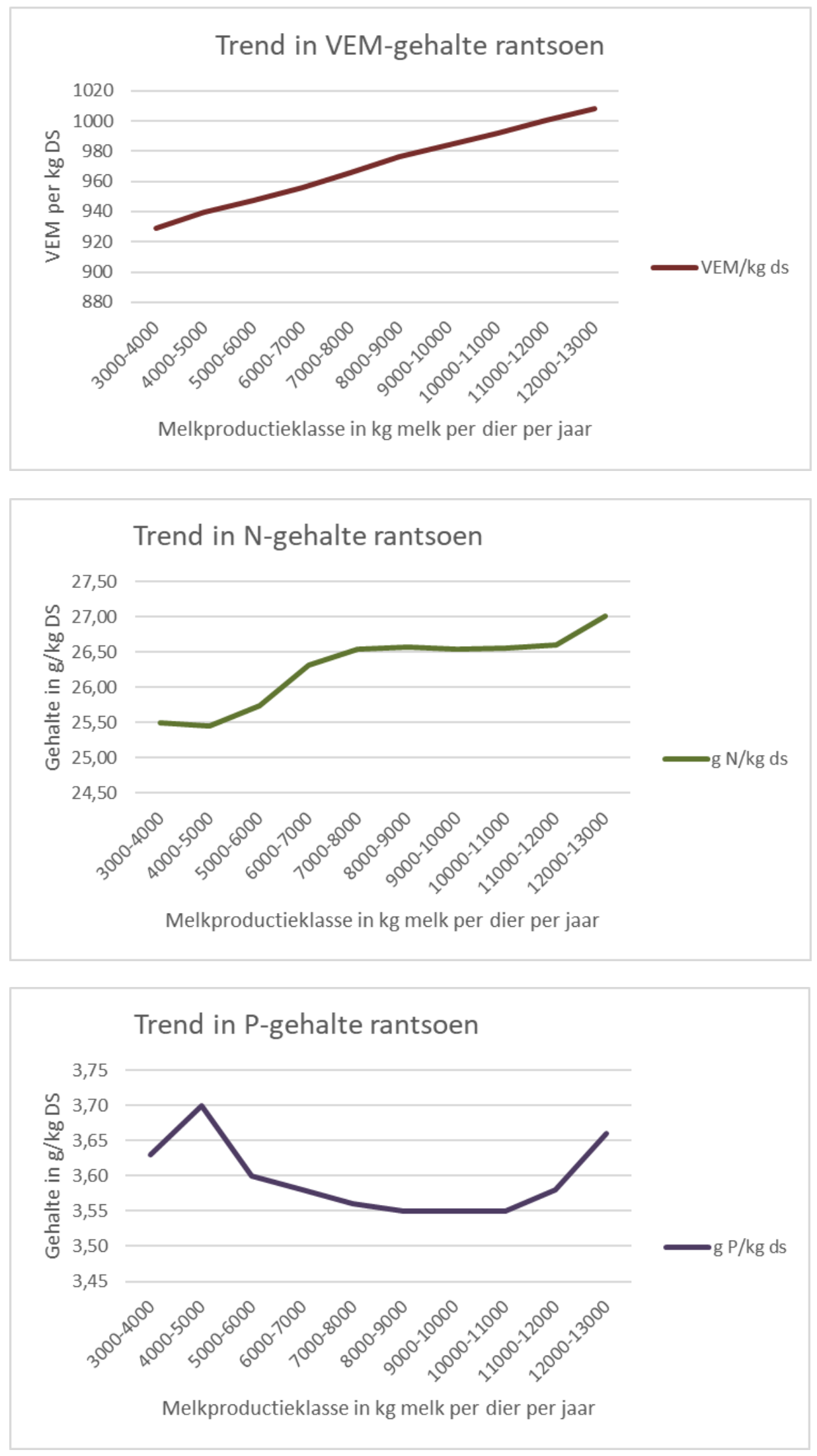


\section{Bijlage 3 Verband tussen $\mathrm{N}$ - en $\mathrm{P}_{2} \mathrm{O}_{5}-$ excretie en melkproductieniveau}
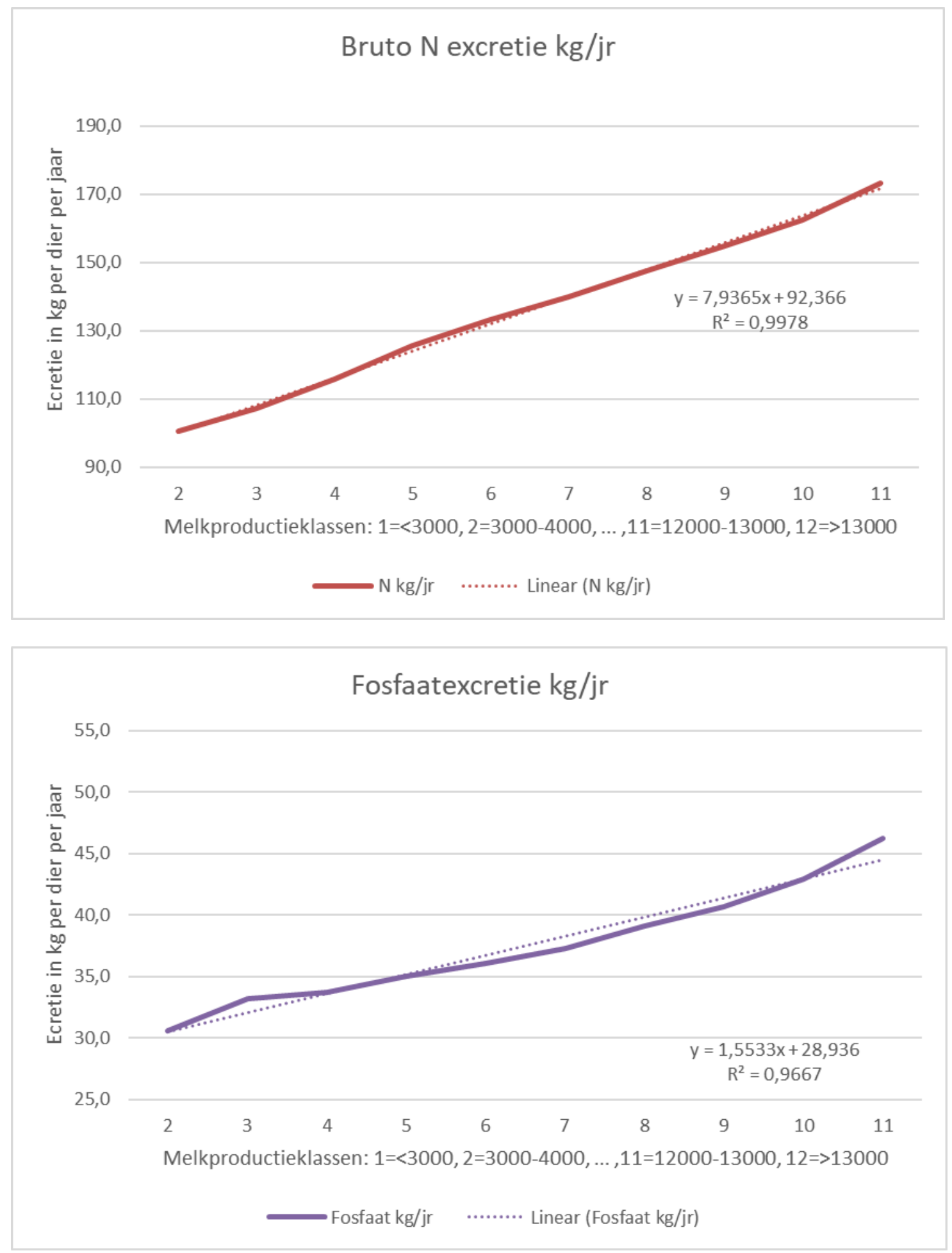


\section{Bijlage 4 Voorstel nieuwe forfaitaire excretietabel: drijfmest}

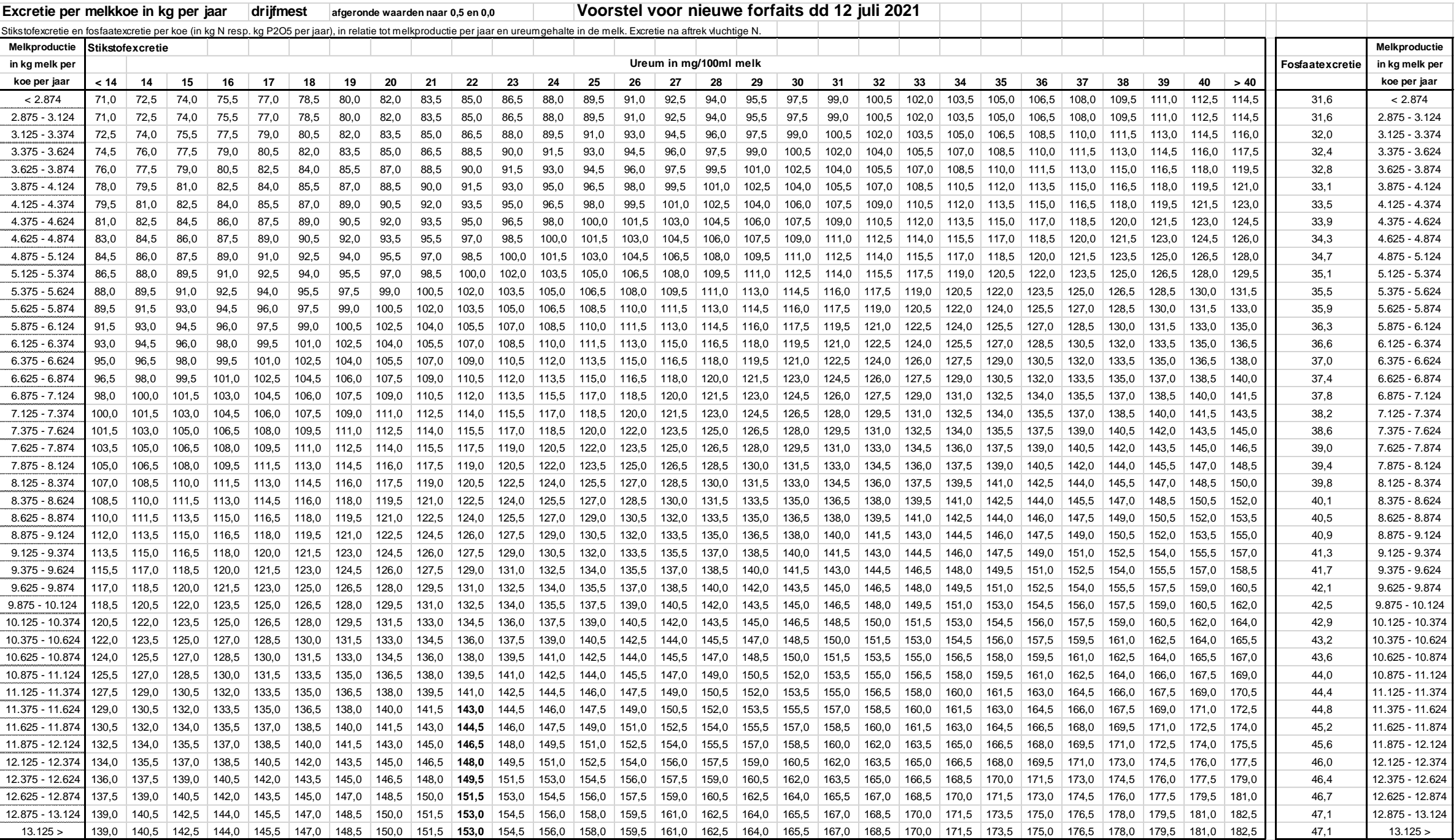




\section{Bijlage 5 Voorstel nieuwe forfaitaire excretietabel: vaste mest}

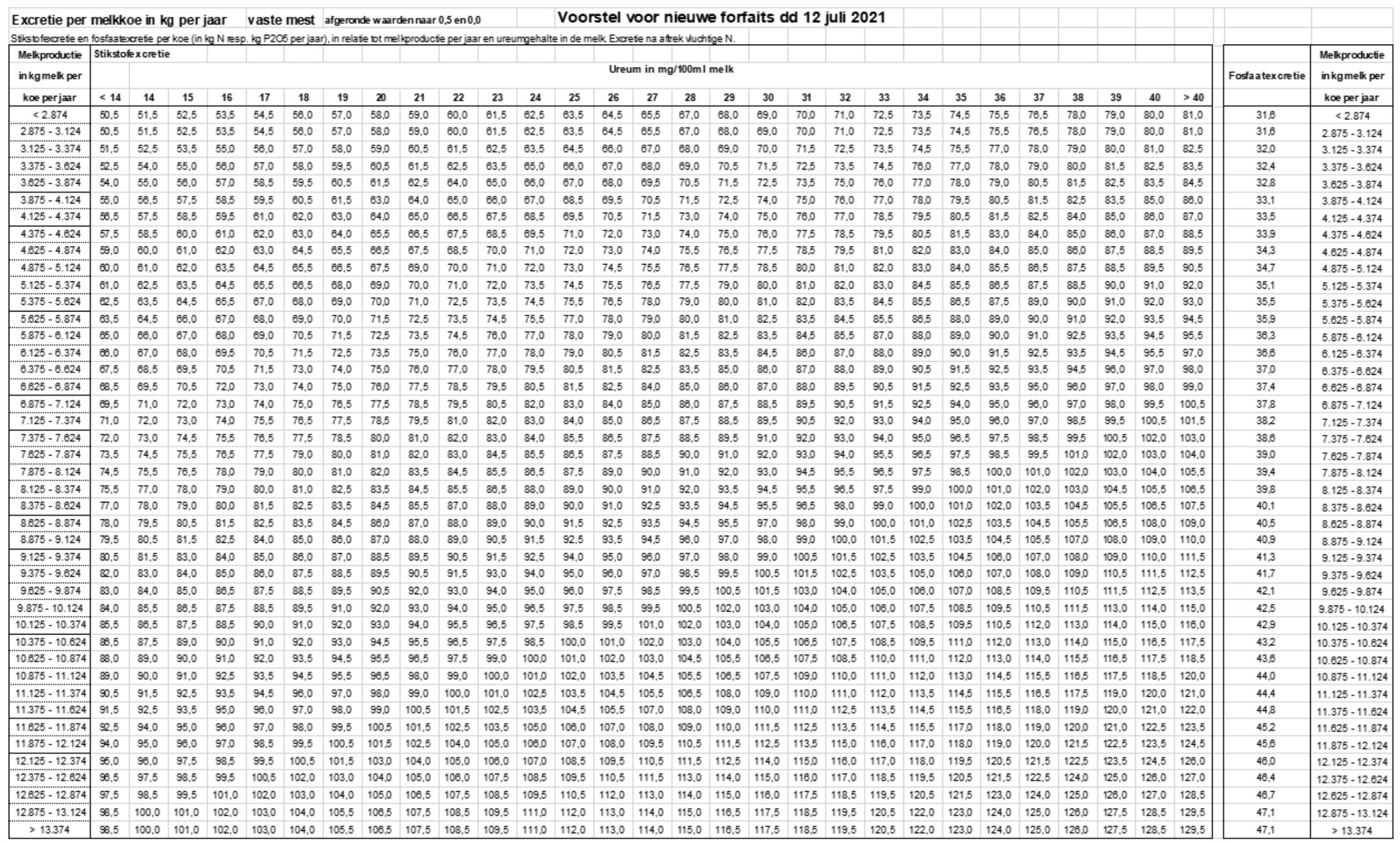



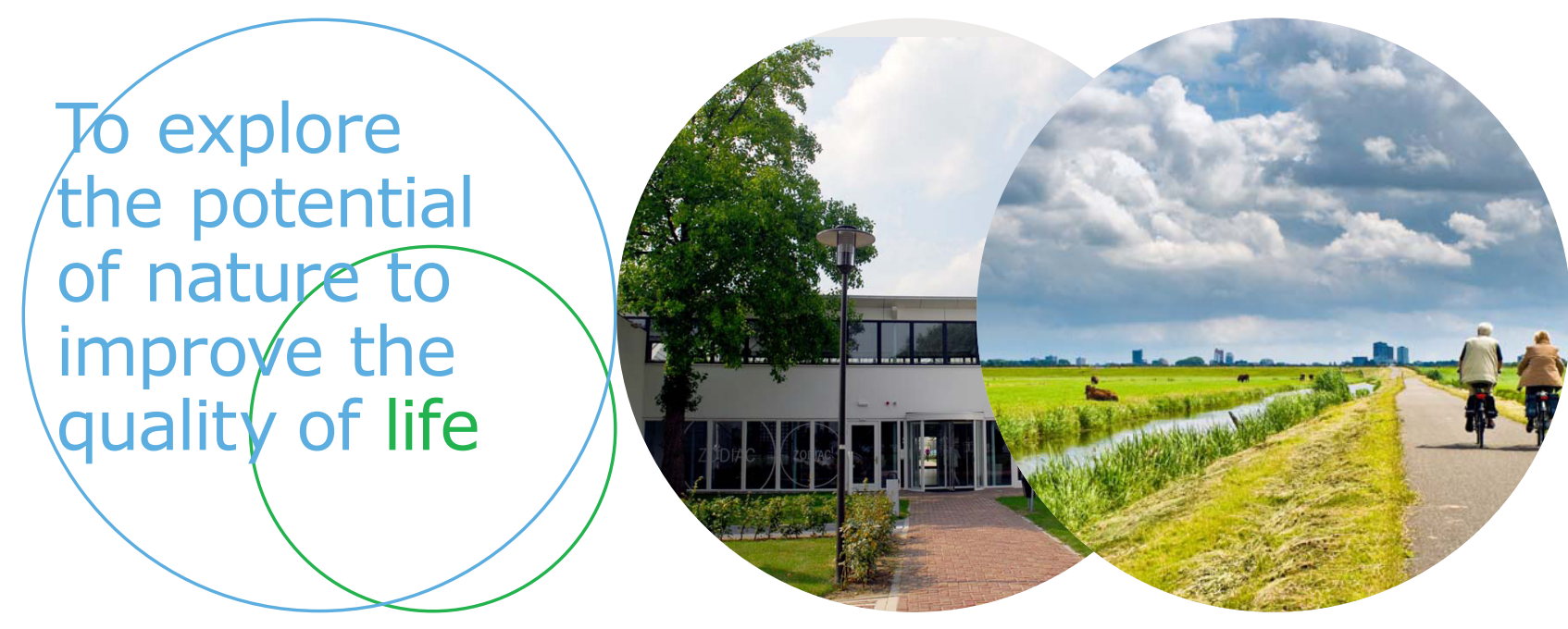

Wageningen Livestock Research Postbus 338

$6700 \mathrm{AH}$ Wageningen

T 0317483953

E info.livestockresearch@wur.nl www.wur.nl/livestock-research
Wageningen Livestock Research ontwikkelt kennis voor een zorgvuldige en renderende veehouderij, vertaalt deze naar praktijkgerichte oplossingen en innovaties, en zorgt voor doorstroming van deze kennis. Onze wetenschappelijke kennis op het gebied van veehouderijsystemen en van voeding, genetica, welzijn en milieu-impact van landbouwhuisdieren integreren we, samen met onze klanten, tot veehouderijconcepten voor de $21 \mathrm{e}$ eeuw.

De missie van Wageningen University \& Research is 'To explore the potential of nature to improve the quality of life'. Binnen Wageningen University \& Research bundelen 9 gespecialiseerde onderzoeksinstituten van Stichting Wageningen Research en Wageningen University hun krachten om bij te dragen aan de oplossing van belangrijke vragen in het domein van gezonde voeding en leefomgeving. Met ongeveer 30 vestigingen, 6.500 medewerkers en 10.000 studenten behoort Wageningen University \& Research wereldwijd tot de aansprekende kennisinstellingen binnen haar domein. De integrale benadering van de vraagstukken en de samenwerking tussen verschillende disciplines vormen het hart van de unieke Wageningen aanpak. 